\title{
UNIVERSITYOF BIRMINGHAM

\section{Application of meteorology-based methods to determine local and external contributions to particulate matter pollution: A case study in Venice (Italy)}

Squizzato, Stefania; Masiol, Mauro

DOI:

10.1016/j.atmosenv.2015.08.026

License:

Creative Commons: Attribution-NonCommercial-NoDerivs (CC BY-NC-ND)

\section{Document Version}

Peer reviewed version

Citation for published version (Harvard):

Squizzato, S \& Masiol, M 2015, 'Application of meteorology-based methods to determine local and external contributions to particulate matter pollution: A case study in Venice (Italy)', Atmospheric Environment, vol. 119, pp. 69-81. https://doi.org/10.1016/j.atmosenv.2015.08.026

Link to publication on Research at Birmingham portal

\section{General rights}

Unless a licence is specified above, all rights (including copyright and moral rights) in this document are retained by the authors and/or the copyright holders. The express permission of the copyright holder must be obtained for any use of this material other than for purposes permitted by law.

- Users may freely distribute the URL that is used to identify this publication.

- Users may download and/or print one copy of the publication from the University of Birmingham research portal for the purpose of private study or non-commercial research.

- User may use extracts from the document in line with the concept of 'fair dealing' under the Copyright, Designs and Patents Act 1988 (?)

- Users may not further distribute the material nor use it for the purposes of commercial gain.

Where a licence is displayed above, please note the terms and conditions of the licence govern your use of this document.

When citing, please reference the published version.

\section{Take down policy}

While the University of Birmingham exercises care and attention in making items available there are rare occasions when an item has been uploaded in error or has been deemed to be commercially or otherwise sensitive.

If you believe that this is the case for this document, please contact UBIRA@lists.bham.ac.uk providing details and we will remove access to the work immediately and investigate. 


\section{Accepted Manuscript}

Application of meteorology-based methods to determine local and external contributions to particulate matter pollution: A case study in venice (Italy)

Stefania Squizzato, Ph.D., Mauro Masiol

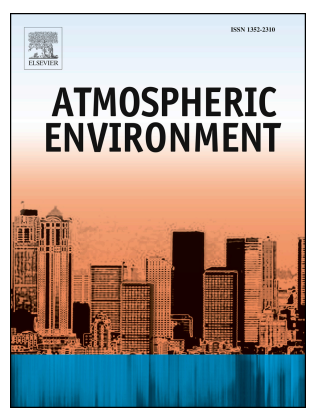

PII:

S1352-2310(15)30271-5

DOI:

10.1016/j.atmosenv.2015.08.026

Reference: $\quad$ AEA 14009

To appear in: Atmospheric Environment

Received Date: 23 April 2015

Revised Date: 7 August 2015

Accepted Date: 10 August 2015

Please cite this article as: Squizzato, S., Masiol, M., Application of meteorology-based methods to determine local and external contributions to particulate matter pollution: A case study in venice (Italy), Atmospheric Environment (2015), doi: 10.1016/j.atmosenv.2015.08.026.

This is a PDF file of an unedited manuscript that has been accepted for publication. As a service to our customers we are providing this early version of the manuscript. The manuscript will undergo copyediting, typesetting, and review of the resulting proof before it is published in its final form. Please note that during the production process errors may be discovered which could affect the content, and all legal disclaimers that apply to the journal pertain. 
*Corresponding author:

Stefania Squizzato, Ph.D.

Dipartimento di Scienze Ambientali, Informatica e Statistica, Università Ca' Foscari Venezia, Dorsoduro 2137, 30123 Venice, Italy

E-mail: stefania.squizzato@unive.it; stefania.squizzato81@gmail.com

Tel: +390412348639 

8

\section{ABSTRACT}

The air quality is influenced by the potential effects of meteorology at meso- and synoptic scales. While local weather and mixing layer dynamics mainly drive the dispersion of sources at small scales, long-range transports affect the movements of air masses over regional, transboundary and even continental scales. Long-range transport may advect polluted air masses from hot-spots by increasing the levels of pollution at nearby or remote locations or may further raise air pollution levels where external air masses originate from other hot-spots. Therefore, the knowledge of ground-wind circulation and potential long-range transports is fundamental not only to evaluate how local or external sources may affect the air quality at a receptor site but also to quantify it. This review is focussed on establishing the relationships among $\mathrm{PM}_{2.5}$ sources, meteorological condition and air mass origin in the Po Valley, which is one of the most polluted areas in Europe. We have chosen the results from a recent study carried out in Venice (Eastern Po Valley) and have analysed them using different statistical approaches to understand the influence of external and local contribution of $\mathrm{PM}_{2.5}$ sources. External contributions were evaluated by applying Trajectory Statistical Methods (TSMs) based on back-trajectory analysis including (i) back-trajectories cluster analysis, (ii) potential source contribution function (PSCF) and (iii) concentration weighted trajectory (CWT). Furthermore, the relationships between the source contributions and ground-wind circulation patterns were investigated by using (iv) cluster analysis on wind data and (v) conditional probability function (CPF). Finally, local source contribution have been estimated by applying the Lenschow' approach.

In summary, the integrated approach of different techniques has successfully identified both local and external sources of particulate matter pollution in an European hot-spot affected by the worst air quality.

\section{Keywords: $\mathbf{P M}_{2.5}$, local and external contributions, meteorology-based methods} (1) 0 61 62 3 4 5 6 67 


\section{INTRODUCTION}

Since mid 90s, the European Community has adopted increasingly stringent standards for reduction of emissions to improve air quality. Such efforts have generally led to an overall improvement of air quality in most of the EU Countries. However, there are still some European regions that are affected by high levels of air pollutants - the so-called hot-spots. Among others, Northern Italy, Benelux, some Eastern Countries and greater urban areas such London and Paris deserve particular attention because of their high population density.

Generally, the main causes of high air pollution levels in hot-spots are the additive effects of: (i) heavy local emissions from many anthropogenic sources; (ii) peculiar weather and/or orographic features limiting the dispersion of locally emitted pollutants and (iii) the regional or even transboundary transport of polluted air masses from external source areas. The first cause is primarily related to the levels of urbanization and industrialization: since most hot-spots lie in densely anthropised areas which are affected by relatively heavy emissions from traffic, energy production and industrial activities. Beyond the local emission sources, air quality may be further influenced by the potential effects of meteorology at meso- and synoptic scales. While local weather and mixing layer dynamics mainly drive the dispersion of sources at small scales, long-range transports affect the movements of air masses over regional, trans boundary and even continental scales and may have two opposite but potentially concurrent effects: (i) they can advect polluted air masses from hot-spots by increasing the level of pollution at near areas or even remote locations, and/or (ii) they may further raise air pollution levels where external air masses originate from other hot-spots. Therefore, the knowledge of ground-wind circulation and potential long-range transports is essential to evaluate how and how much local or external sources may affect the air quality at a receptor site. The main goal of this study is to establish a relationship among $\mathrm{PM}_{2.5}$ sources, meteorological condition and air mass origin through the application of a multiple methods and tools. The results of a recent source apportionment study carried out in Venice (Eastern Po Valley) over three sites were evaluated using various statistical approaches to determine the influence of external and local contribution on identified $\mathrm{PM}_{2.5}$ sources. External contributions were evaluated by applying Trajectory Statistical Methods (TSMs) based on back-trajectory analysis: (i) back-trajectories cluster analysis; (ii) potential source contribution function (PSCF) and (iii) concentration weighted trajectory (CWT). Furthermore, the relationships between the source contributions and ground-wind circulation patterns were investigated using (iv) cluster analysis on wind data and (v) conditional probability function (CPF). Finally, local source contributions have been estimated following the approach proposed by Lenschow et al. (2001).

The application of multiple techniques has identified both local and external sources of particulate matter pollution in an European hot-spot affected by worst air quality. We strongly believe that the 
proposed approaches will be useful for the future air quality assessment studies and reduction strategies.

\section{MATERIALS AND METHODS}

\subsection{Study area}

While Northern Italy has fulfilled the same mitigation processes adopted by other European Countries towards emissions reduction, it has not fully benefited in terms of substantial reduction of air pollution. As of today, the Po Valley is one of the most polluted areas in the Europe for particulate matter (PM), ozone and nitrogen oxides (EEA, 2015). Local emissions are expected to be more important in Po Valley than in other European areas (Maurizi et al., 2013) although Gilardoni et al. (2011) showed that local sources mainly affect fine PM (aerodynamic diameter less than $2.5 \mu \mathrm{m}, \mathrm{PM}_{2.5}$ ) during winter while the influence of regional air masses from the nearby Po Valley dominates in summer. Moreover, the generation of secondary aerosol is known to form over the Valley that rapidly build-up air pollution after clean-air episodes which is governed by the particular topology and meteorological conditions of the plain (Larsen at al., 2012; Masiol et al., submitted).

Venice is located between the eastern edge of the Po Valley and the Adriatic Sea. Along with the city of Mestre, they form a large coastal urban municipality hosting 270,000 inhabitants. The emission scenario includes sources of PM such as high density residential areas, heavy traffic roads mostly congested during peak hours, a motorway and a motorway-link part of the main European routes E55 and E70, an extended industrial area (Porto Marghera) with a large number of different installations, including incineration plants and a large thermoelectric power plant burning coal and refuse-derived fuel, the artistic glassmaking factories in the island of Murano, heavy shipping traffic providing public/commercial and tourist transports and an international airport. The apportionment of the most relevant PM sources and their spatial and seasonal changes (Masiol et al., 2012a;2014b) as well as the regional and local influence of PM and secondary aerosol have been investigated (Squizzato et al., 2012; Masiol et al., submitted). Moreover, the potential influence of local or longrange transports upon PM mass and PM-bound pollutants were investigated in a series of sparse studies (e.g., Masiol et al., 2010; 2012a,b; Squizzato et al., 2012; 2014), but its role on standard breaching has not yet comprehensively assessed.

\subsection{Experimental}

A year-long $\mathrm{PM}_{2.5}$ sampling campaign (February 2009 - January 2010) was carried out at the three sites indicative of different environments (Fig. 1): 
- a semi-rurat background coasta CCFPTED) MANUSCRIPT local emission sources;

- an urban background site (URB) established in a high density residential zone of Mestre, very close $(\sim 50 \mathrm{~m})$ to the main traffic roads;

- an industrial site (IND) placed downwind of Porto Marghera and the surrounding area that has extensive road and shipping traffic.

Four time periods were selected for chemical analysis: spring (March-April 2009), summer (JuneJuly 2009), autumn (September-October 2009) and winter (December 2009-January 2010). Filters were cut into two portions: one to determine major inorganic ions via ion exchange chromatography (IC) (after water extraction) and the second to quantify elements via ICP-OES and ICP-MS after acid digestion. Analytical methods are reported elsewhere (Squizzato et al., 2012; 2014). Common weather data including wind speed and direction, air temperature, relative humidity, solar radiation and precipitations were hourly measured at two stations near the sampling sites (Fig. 1): ARPAV Cavallino-Treporti was chosen as being representative of SRB, while EZI5 (part of the network of Ente della Zona Industriale di Porto Marghera) for URB and IND. Wind data were homogenized and appropriate corrections were applied when necessary. The wind speeds $<0.5 \mathrm{~m}$ $\mathrm{s}^{-1}$ (anemometer detection limit) were assumed as calm wind whereas uncertain data or hours with fast changes in wind direction were excluded from the analysis.

\subsection{Overview of back-trajectories and trajectory-based models}

There are number of methods that are currently used in air pollution studies to account for longrange transports (Fleming et al., 2012 and references therein). Back-trajectory analysis is a commonly-used tool for tracing the history of air masses passing over a location at a defined time. Briefly, interpolated measured or modelled meteorological fields are used to infer backward in time the most probable paths of infinitesimally small particles of air that at the time zero are located at a starting point. In this study, back-trajectories were computed using HYSPLIT (Draxler and Rolph, 2015; Rolph, 2015). Our model set-up parameters included 4 days (-96 h) run time, starting height of $20 \mathrm{~m}$ AGL, NCEP/NCAR Reanalysis data fields.

It is important to stress that back-trajectories are potentially associated with large uncertainties (Stohl, 1998) mostly due to the oversimplification of the atmosphere in that dispersion is not accounted for. Moreover, back-trajectories may be highly variable when run at different hours in a day, causing further uncertainty when associated with daily pollutant data. To overcome large uncertainties, the confidence of back-trajectories was tested using different starting heights and hours: errors associated with a single trajectory were reduced by simulating four trajectories for each sampling day (at 3:00, 9:00, 15:00 and 21:00). Taking into account the range of associated 
uncertainties, the use of multiple trajectory-based models over long periods may yield more robust results than the use of individual trajectories and may provide useful information about the external source areas.

Back-trajectory modelling combined with atmospheric concentrations measured at the receptor site are commonly referred to Hybrid Receptor Models (HRMs) (Han et al., 2007) or Trajectory Statistical Methods (TSMs) (Kabashnikov et al., 2011; Brereton and Johnson, 2012). Most used TSMs are: Potential Source Contribution Function (PSCF) (Hsu et al., 2003; Pekney et al., 2006; Kim et al., 2005; Gildemeister et al., 2007; Han et al., 2007), Gridded Frequency Distributions (GFD) (Weiss-Penzias et al., 2011), Concentration Fields Analysis (Rutter et al., 2009), Concentration-Weighted Trajectory (CWT) (Seibert et al., 1994) and Residence Time Weighted Concentration (RTWC) (Hsu et al., 2003; Han et al., 2007). All these methods essentially count the frequency of back-trajectory segment endpoints in grid cells that make up the geographical domain of interest for the receptor site (Cheng et al., 2013).

In this study three methods have been used, moreover an approach to determine the uncertainties associated with PSCF is also proposed. Details of each method are provided as supplementary material:

- Cluster analysis on back-trajectories: the principal purpose of back trajectories clustering is to group trajectories having similar geographic origins and histories. The subsequent coupling of clusters with chemical data associated to air pollutants is a simple but powerful way to infer insights into the potential contribution of long-range transports from different pathways.

- PSCF: It was initially developed to identify the likely locations of the regional PM sources (Lee and Hopke, 2006; Pekney et al., 2006) and calculates the probability that a source is located at latitude $i$ and longitude $j$. The basis of PSCF is that if a source is located at coordinates $i$ and $j$, an air parcel back-trajectory passing through that location indicates that material from the source can be collected and transported along the trajectory to the receptor site. The PSCF value can be interpreted as the conditional probability that concentrations larger than a given criterion value are related to the passage of air parcels through a grid cell with this PSCF value during transport to the receptor site (Hsu et al., 2003). This method is deficient in the determination of the statistical significance of its outcome and is suitable for identifying possible source regions (Dvorska et al., 2008 and references therein). Generally, PSCF values of $0.00-0.50$ are considered as low whereas the values of $0.51-1.00$ are considered as high.

- $C W T$ : the concentration weighted trajectory is a method of weighting trajectories with associated concentrations (Hsu et al., 2003). In this procedure, each grid cell gets a weighted 
concentration obtained by averaging sample concentrations that have associated trajectories that crossed that grid cell as follows, i.e. each concentration is used as a weighting factor for the residence times of all trajectories in each grid cell and then divided by the cumulative residence time from all trajectories (Hsu et al., 2003; Cheng et al., 2013). In summary, weighted concentration fields show concentration gradients across potential sources and highlight the relative significance of potential sources (Hsu et al., 2003).

- Evaluation of the uncertainties associated with PSCF: despite the scientific literature proposes different methods, at today there is not a unique standardized technique for assessing the better estimates of the PSCF probabilities and their uncertainties. For example, Pekney et al. (2006) used weighting functions multiplied by PSCF values for reducing the effect of spurious large ratios in grid cells, while Lupu and Maenhaut (2002) and Hopke et al. (1995) applied bootstrap techniques to estimate the statistical significance and the uncertainties of the calculated PSCF values, respectively. Bootstrapping is not yet implemented in the Openair package, however the package used weighted PSCF values depending on the number of values in each cell (weights factors range from 0.15 to 2 ). The bootstrapping techniques are widely used in chemometrics and provide accurate tools for yielding estimates in cases where other methods are simply not available (Wehrens et al., 2000). This way, the uncertainties associated to PSCF values in this study were estimated externally by using a non-parametric bootstrap method. Briefly, $n=500$ subsamples including $80 \%$ of the total number of trajectories were re-sampled without replacement from the original dataset and PSCF was then re-run for each subsample. The 500 new PSCFs maps were then merged to assess the average values and their associated standard deviations for each cell in the grid domain. The uncertainties over the average results were then expressed as average \pm standard deviation.

\subsection{Overview of wind-based methods}

The effectiveness of coupling air pollution data with wind data fields for identifying and accounting local sources was largely demonstrated in a number of studies using very different approaches and techniques (e.g., Ashbaugh et al., 1985; Kaufmann and Whiteman, 1999; Kim et al., 2003; Carslaw et al., 2006; Viana et al., 2006: Masiol et al., 2012a; Uria-Tellaetxe and Carslaw, 2014). Such approaches are based on the assumption that air pollutants emitted from a source are transported by local winds. As a consequence, the levels of pollution recorded at a receptor site under downwind conditions from the source should be higher when air blows from different sectors. However, these methods generally disregard many issues linked to the dispersion of pollutants in the atmosphere, e.g., the influence of atmospheric stability and turbulence on dilution of pollutants, the effects of the 
mixing layer height on wind dynamics, the concentration-wind speed dependencies for certain pollutants, the street canyon and urban canopy layer effects, etc. Despite the limitations, methods for coupling air pollution with wind data are very useful in extracting information on local source contributions and locations. Wind-based methods applied in this study aim to couple source apportionment results with local wind fields recorded at ground:

- Cluster of wind data: The hourly data of wind speed and direction from the weather station were processed by extracting their scalar components $\mathrm{u}$ and $\mathrm{v}$ relative to the North-South and West-East axes (Kaufmann and Whiteman, 1999; Darby, 2005). In this study the hourly values of the components were separately summed to obtain daily data, which represents the resultant vector of the air movement. A hierarchical cluster analysis using the Ward's method and the squared Euclidean distance measure were then performed on these components.

- $\quad C P F$ : the conditional probability function (Kim et al., 2003; Kim and Hopke, 2004) analyses local source impacts from varying wind directions using the source contribution estimates from PMF coupled with the time-resolved wind directions. The CPF estimates the probability that a given source contribution from a given wind direction will exceed a predetermined threshold criterion. The sources are likely to be located at the directions that have high conditional probability values (Kim et al., 2005). Details are reported as supplementary material.

\subsection{Lenschow approach}

Local contributions can be estimated using the method proposed by Lenschow et al. (2001). Briefly, the method essentially compares the PM levels and components (PMF sources, in this case) measured in sites affected by different emission scenarios (semi-rural, urban and industrial, in this case). In this study we assumed that: (i) the differences of particulate matter and its chemical components between URB and IND can be attributed to the local influence of urban and industrial area, respectively and (ii) SRB represents a rural background station affected by regional sources with little contribution from the urban and industrial area. Only URB and IND samples with higher concentration than SRB have been considered.

\section{RESULTS AND DISCUSSION}

\subsection{Overview on PMF results}

A multiple-site positive matrix factorization receptor model was performed over $448 \mathrm{PM}_{2.5} \mathrm{Samples}$ and 19 variables. Details of adopted methods and results are exhaustively reported in Masiol et al. (2014b). Six factors associated with potential sources were extracted and apportioned, namely: 
- secondary sulphate (made up of $\mathrm{SO}_{4}{ }^{2-}$ and $\mathrm{NH}_{4}^{+}$);

- ammonium nitrate and combustions $\left(\mathrm{NO}_{3}{ }^{-}, \mathrm{NH}_{4}{ }^{+}\right.$plus combustion tracers $\mathrm{K}^{+}$and $\left.\mathrm{Cl}^{-}\right)$ linked to gas-to-particles conversion processes involving $\mathrm{NH}_{3}$ and $\mathrm{NO}_{\mathrm{x}}$ (emitted both from industries and traffic) and various combustion processes: $\mathrm{K}^{+}$was associated to biomass combustion processes (Kundu et al., 2010) and the association $\mathrm{K}^{+}-\mathrm{Cl}^{-}$was attributed to gasoline vehicle emissions (Spencer et al., 2006);

- fossil fuels $(\mathrm{V}, \mathrm{Ni})$;

- traffic, mainly related to primary traffic emissions and road dust resuspension (Fe, $\mathrm{Ti}, \mathrm{Mn}$, $\left.\mathrm{Cu}, \mathrm{Ba}, \mathrm{Mg}^{2+}\right)$;

- $\quad$ industrial $\left(\mathrm{Zn}, \mathrm{Pb}, \mathrm{Mg}^{2+}\right)$;

- glassmaking (As, Cd).

The quantification of sources revealed that on annual basis the most impacting source in all the sites is ammonium nitrate and combustions, accounting for $\sim 12 \mu \mathrm{g} \mathrm{m}^{-3}$ at all the sites, i.e. $47 \%$ of the $\mathrm{PM}_{2.5}$ mass in SRB and $38 \%$ in URB and IND. Ammonium sulphate is the second largest contributor, accounting for $5.6 \mu \mathrm{g} \mathrm{m}^{-3}$ (24\% in SRB and $17 \%$ in URB and IND sites). As a matter of fact, such sources account for most of the $\mathrm{PM}_{2.5}$ mass (71\% in SRB and 55\% in URB and IND) and their mass contributions are identical at all the sites, indicating that they are homogeneously distributed throughout the area.

On the contrary, the remaining sources show different and variable contributions at the three sites. This result is an early indication of their potential strong component of local origin: industrial source contributes $7.1 \mu \mathrm{g} \mathrm{m}^{-3}$ in IND, $4.8 \mu \mathrm{g} \mathrm{m}^{-3}$ in URB and $3.6 \mu \mathrm{g} \mathrm{m}^{-3}$ in SRB, followed by road traffic $\left(5.5 \mu \mathrm{g} \mathrm{m}^{-3}\right.$ in URB, $3.3 \mu \mathrm{g} \mathrm{m}^{-3}$ in IND and $0.6 \mu \mathrm{g} \mathrm{m}^{-3}$ in SRB $)$, fossil fuels $\left(2.9 \mu \mathrm{g} \mathrm{m}^{-3}\right.$ in IND, $2.1 \mu \mathrm{g} \mathrm{m}^{-3}$ in URB and $1.9 \mu \mathrm{g} \mathrm{m}^{-3}$ in SRB) and glassmaking $\left(1.7 \mu \mathrm{g} \mathrm{m}^{-3}\right.$ in URB, $1.1 \mu \mathrm{g} \mathrm{m}^{-3}$ in IND and $1 \mu \mathrm{g} \mathrm{m}^{-3}$ in SRB).

\subsection{Results of trajectory-based methods}

Seven cluster are identified using the measure of the Euclidean distance and are named according to their common origin. Five clusters are linked to long-range transports from Atlantic, Central Europe, Northern Europe, Eastern EU and Western Mediterranean. Remaining two clusters are associated with more local transports from East-Austria and from South/Central Italy. Fig. 1 shows the frequency of trajectories passing through the grid cells in the grid domain and the average trajectories associated to each identified cluster. The number of trajectories in each cluster is reported in Table 1: a large number of trajectories pass over the Po Valley or blow from EastEurope. These latter two clusters depict the two overwhelming pathways during the sampling 
campaign. The potential effects of long-range/regional transports are then assessed by averaging the levels of $\mathrm{PM}_{2.5}$ and source contributions overall the study period: Table 1 reports the average concentrations calculated for each cluster as well as the percentage of differences with respect to the mean of the overall sampling period in the semi-rural background coastal site as considered affected to regional sources with little contribution from the urban and industrial area. Generally, results show an evident increase of $\mathrm{PM}_{2.5}$ and ammonium sulphate when air masses originated from Eastern Europe $(+40 \%$ and $+124 \%$, respectively), ammonium nitrate increases when air masses come from Atlantic and Western Mediterranean area (+35\% and $+17 \%$, respectively) and fossil fuel source when air masses blow from South $(+60 \%)$. On the contrary, industrial, glass making and traffic only slightly increases when masses move from Eastern Europe and in East-Austria.

Results also show significant drops of concentrations of $\mathrm{PM}_{2.5}$, ammonium nitrate and fossil fuels for Central and Northern Europe clusters.

Generally, PSCF and CWT analyses return very similar results, but they give some more clues about the potential source location. Resulting PSCF plots for $\mathrm{PM}_{2.5}$ and PMF sources are shown in Fig. 2, while their associated uncertainties are provided as Figure SI1a and SI1b. Maps are calculated over the whole sampling campaign and are not smoothed because the low number of trajectories used (only trajectories with concentrations $>75$ th percentile). Uncertainties calculated by bootstrapping the trajectories are generally low for all the variables, allowing to extract the following information. High probabilities (range 0.5-0.6) of high levels of fossil fuels combustion and ammonium nitrate are found in Po Valley, while industrial, ammonium sulphate and road traffic contributions show elevated probabilities in East-Europe (range 0.3 - 0.7) and glass-making source from Eastern and Southeastern Countries. With respect to the glass-making sources, it should be noted that near SRB sampling site, there is a local glass-making industry. Hence, the increase of probability can be due to the mix of local air masses with external air masses and not necessarily only from an external contribution.

Although CWT distributes concentration along the trajectories similarly to PSCF, this method has an advantage that it distinguishes major sources from moderate ones by calculating concentration gradients (Hsu et al., 2003). CWT maps presented in Fig. 3a and 3b demonstrates smoothed data split for sampling seasons. The concentration gradients indicate Po Valley and East-Europe as significant contributors of $\mathrm{PM}_{2.5}$ and related PMF sources. Seasonally, high external contribution can be observed during spring and winter, reaching $40 \mu \mathrm{g} \mathrm{m}^{-3}$ and $30 \mu \mathrm{g} \mathrm{m}^{-3}$ for $\mathrm{PM}_{2.5}$ and ammonium nitrate, respectively. In addition, other sources show potential external contribution during summer (fossil fuels combustion and glass-making) and autumn (ammonium sulphate, 
industrial, road-traffic and glassmaking). In particular, the external contributions of ammonium sulphate from East-Europe reach $14 \mu \mathrm{g} \mathrm{m}^{-3}$ during autumn and winter.

Results of trajectory-based methods are interesting for a number of reasons and may have significant implications for air quality assessment and mitigation measures adopted, or to adopt, in the study area. $\mathrm{PM}_{2.5}$ is a critical pollutant in Venice and in the Northern Italy due to the frequent exceeding of European air quality standards.

Ammonium nitrate and combustion source is the main contributor of $\mathrm{PM}_{2.5}$ apportioned by the PMF analysis and also has PSCF and CWT maps quite identical to $\mathrm{PM}_{2.5}$ for source locations, probability/concentrations and seasonal trends. Under this scenario, it is evident that it plays a key role in breaching of $\mathrm{PM}_{2.5}$ standards. Although the source apportionment has not separated the two main components behind this source (likely because of the limitation to distinguish elemental and organic carbon), results indicate they have likely a similar potential origin, which is principally linked to weather conditions and anthropogenic emissions. Nitrate aerosol mainly derives from the atmospheric oxidation of $\mathrm{NO}_{2}$ and the combustion of fossil fuels (road traffic and industries) is by far the dominant source of nitrogen oxides in Europe. Moreover, nitrate is a semi-volatile compound and its partitioning is favoured toward particle-phase in coldest periods. Similarly, combustion emissions generally increase in coldest periods due to contributions from domestic heating and the recent increase of the number of pellet stoves in use in Northern Italy is expected to boost this trend. Results of PSCF and CWT show a strong potential contribution from regional transports from Po Valley (spring, autumn, winter) and from Central (spring) and Eastern (winter) Europe. These findings are in line with the EEA airbase maps (EEA, 2015), which clearly show that Northern Italy, Central Europe and in minor extent some Eastern Countries are affected by the highest annual average levels of measured $\mathrm{NO}_{2}$. The seasonal behaviour is also consistent with results, since spring and winter were the coldest periods during the sampling campaign. Moreover, carbonaceous matter that can be considered mainly related to combustion processes presents the highest contribution in central Europe and the ratio $\mathrm{TC} / \mathrm{PM}_{10}$ is generally larger in this area (Putaud et al., 2010).

The increasingly high standard for fossil fuels and industrial emissions in Central Europe have lead a significant drop of $\mathrm{SO}_{2}$ levels in Central and Western Europe to concentrations well below $10 \mu \mathrm{g}$ $\mathrm{m}^{-3}$ (EEA, 2015). However, $\mathrm{SO}_{2}$ still reach high concentrations $\left(>10 \mu \mathrm{g} \mathrm{m}^{-3}\right)$ in some Eastern and Southeastern locations (e.g., Poland, Romania, Serbia, Bulgaria, Greece and Turkey). Since $\mathrm{SO}_{2}$ is the main precursor of sulphate aerosol and ammonium sulphate account for $17 \%-24 \%$ of total 
$\mathrm{PM}_{2.5}$ mass in Venice, results of this study indicate a strong influence of trans-boundary transports. However, many studies attribute $\mathrm{SO}_{2}$ and ammonium sulphate aerosol in the Mediterranean area also to the high maritime traffic in particular for the role of $\mathrm{SO}_{2}$ as gaseous precursor on secondary formation processes (e.g.: Cesari et al., 2014; Salameh et al., 2015), nevertheless shipping emissions are not the main trigger of PM pollution episodes encountered in the Mediterranean basin (Salameh et al., 2015).

Moreover, a recent study conducted in the Veneto region (Masiol et al., 2015) demonstrated that sulphate levels are constant, showing similar daily trends and mean throughout the region and highlighting that both the accumulation/removal processes in the region are similar. In regards to $\mathrm{SO}_{2}$, Sacca Fisola (a Venice monitoring station close to the Grand Canal where cruise ships pass) shows similar concentration to the IND site on annual mean (ARPAV, 2011). IND site is affected by industrial activities (petrochemical plant, coal power plant) and shipping traffic. Therefore, despite maritime traffic contributes strongly to pollutant source in the coastal area, in the study area it can be considered negligible with respect to other contributions.

Although glass-making industry source is considered of local origin because the emissions from the Island of Murano, the high probability in PSCF and the high concentration gradient in CWT are not surprising. The trajectories coming from SE are often associated with typical wind regimes called "Scirocco", which bring hot and wet air masses from the Adriatic region. Under this wind regime, the Island of Murano is just upwind to the sampling sites and the results of trajectory analyses may be subjected to an artefact. However, a transboundary origin cannot be excluded for this source. The elemental tracer in this source (As and Cd) can be also linked to industrial processes, mining and other anthropogenic activities (Moreno et al., 2006; Lim et al., 2010).

\subsection{Cluster on wind data and CPF}

Five groups of days with similar atmospheric circulation patterns were found in data obtained from both the weather stations. A $15 \%$ cut-off level has been applied while processing data. Average wind speeds (Ws) and predominant directions were then plotted for the full period and each group in Fig. 4. Kruskal-Wallis test has been applied to highlight which sources are statistically different ( $\mathrm{p}$ value $<0.05$ ) respect to the average conditions (all sampled days) among the identified groups.

Group $1(\mathrm{~N}=44)$ includes days with prevailing wind from quadrant I, with high speeds and very low percentage of calm wind hours $(0.5 \%)$. Fast north-easterly winds called "bora" form peculiar cold and gusty downslope windstorms blowing over the Adriatic Sea and bringing air masses from Northern Europe. Generally, in the study area these conditions may cause increased sea-spray 
generation and dispersion of pollutants (Masiol et al. 2010). In fact, in these conditions, a general decrease of all contributions can be observed in all three sites, in particular for industrial, glassmaking and ammonium nitrate show a clear drop in contributions $(-54 \%,-48 \%,-83 \%$ on mean, respectively) and are statistically different to the full period mean. Group 2 (N=93) includes days with middle intensity winds blowing mainly from $\mathrm{N}-\mathrm{NE}$, other directions are negligible. This group is mainly composed of autumn and winter days and can represent the atmospheric circulation occurring during cold periods. In these days, fossil fuels contribution decrease and, on the contrary an increase in industrial component can be observed in IND (+39\%) and URB sites (+42\%) as well as traffic ( $+35 \%$ and $+34 \%$ in IND and URB, respectively). This shows that the wind speed is decisive in the dispersion of pollutants and even a small decrease could lead to a widespread accumulation of pollutants.

Group $3(\mathrm{~N}=75)$ includes conditions with $\sim 50 \%$ of winds from quadrant I and $~ 50 \%$ of winds from the quadrant II. Winds from quadrant II are frequent mainly during the warmer seasons, in fact no winter days are included due to the sea-breeze circulation, but they can describe a peculiar wind pattern called "Scirocco," bringing warm air masses from southern Adriatic and Mediterranean regions. Fossil fuels, industrial and ammonium nitrate are statistically different to the full period mean: fossil fuels shows an increase in contribution $(+49 \%$ and $+21 \%$ in IND and URB, respectively) while industrial and ammonium nitrate contributions decrease with the lowest contributions reached in SRB (-51\% and $-55 \%$, respectively). The highest wind speed (2.0 - $2.7 \mathrm{~m} \mathrm{~s}^{-}$ ${ }^{1}$ ) favours the dispersion of these sources but enhance the transport of fossil fuel related compounds. Moreover, the decrease on ammonium nitrate contribution can be also linked to the fact that winter samples (enriched in nitrate and ammonium) are not included in this group.

Group 4 includes only spring days $(\mathrm{SRB}=31$; IND=27; $\mathrm{URB}=29)$ characterized by wind blowing from SE. In these conditions clean air from Adriatic Sea results in low contributions of all sources except fossil fuels combustion. Similar to group 3, wind from II quadrant enhances the input of fossil component $(+44 \%,+80 \%$ and $+61 \%$ in IND, URB and SRB respectively). Group $5(\mathrm{~N}=11)$ includes days characterized by a high percentage of wind calm (about $20 \%$ ), low speeds (1 - 1.9 $\mathrm{m} / \mathrm{s}$ ) and no prevailing direction. These "stagnation" conditions were associated to the rise of locally emitted pollutants (Masiol et al., 2010); in fact an increase of industrial and ammonium nitrate contribution can be observed in all three sites ( $+30 \%$ and $+50 \%$ on mean, respectively). Among the identified sources, industrial, ammonium nitrate and fossil fuel combustion appear more sensitive to atmospheric circulation changes. In particular, fossil fuels contribution enhance in days characterized by wind blowing from SE (group 3 and 4) while industrial and ammonium nitrate levels are most affected by the different wind speed. Despite this, our analysis does not help in 
understanding the source locations with respect to each sampling site, may be due to a widespread pollution condition that affects the study area.

In this view, the application of CPF method provides the most probable sources of pollution for each location. $\mathrm{CPF}$ values for each sources that apportion to $\mathrm{PM}_{2.5}$ are plotted in polar coordinates in Fig. 5. CPF permits to better highlight the possible location of each identified source. The highest probabilities are reached to the sources characterized by a significant local contribution (traffic, industrial and glass-making) whereas the probability associated to ammonium nitrate and ammonium sulphate tends to be lower according to their secondary origin and the homogeneous distribution in the study area (Squizzato et al., 2012).

Traffic shows high probability toward east in all three sites and south in URB and IND site in correspondence with the street located near the sampling sites.

In SRC the highest probability for industrial contribution is reached toward north: this may be due to the influence of the engineering works for the construction of high-tide preventing dams at the Venice Lagoon entrance.

The highest probability for glass-making is reached toward south and east in IND site due to the emissions of local industries in Murano Island, located east of the site. Fossil fuels shows the highest probability associated to wind blowing from SE. This highlights the influence of the combustion processes occurring in the industrial zone on URB and IND site. In regards to SRB site, the increase of probability can be due to the ship traffic toward Venice.

\subsection{Lenschow approach}

Yearly, local sources contribute for $9.8 \mu \mathrm{g} \mathrm{m}^{-3}$ of $\mathrm{PM}_{2.5}$ amounting to $28 \%$ and $30 \%$ of masses in URB and IND site respectively (Table 2). Seasonally, the highest local contributions were observed in spring and winter both in URB $\left(11.3 \mu \mathrm{g} \mathrm{m}^{-3}\right.$ and $\left.15.5 \mu \mathrm{g} \mathrm{m}^{-3}\right)$ and IND site $\left(10.4 \mu \mathrm{g} \mathrm{m}^{-3}\right.$ and $12.5 \mu \mathrm{g} \mathrm{m}^{-3}$ ) whereas the highest percentage was reached in summer (31\% in URB and $40.5 \%$ in IND site). Among the identified sources, ammonium nitrate and ammonium sulphate show the lowest local contribution (31\% and $26 \%$ respectively) confirming the results obtained applying the CWT, highlighting high external contribution for these sources. Traffic sources show the highest local contribution ( $83 \%$ and $74 \%$ in URB and IND site respectively), followed by glass making, industrial and fossil fuels combustion.

During heavy PM events ( $>75^{\text {th }}$ percentile) local contribution on PM expressed in $\mu \mathrm{g} \mathrm{m}^{-3}$ increases $\left(20.4 \mu \mathrm{g} \mathrm{m}^{-3}\right)$ whereas the local contribution percentages are similar to the average conditions (28.4 $\%$ and $27.7 \%$, respectively). Nevertheless, considering the mass percentage, no significant variations have been observed for all periods and samples for PM and its sources. Fossil fuels 
source represents an exception: during these events the local contribution reaches the $56 \%$ and the

$48463 \%$ in URB and IND respectively that is about twice the average percentage of samples.

485 On this basis, local contribution is important and it is strongly affected to local atmospheric

486 circulation that governs the level of PM and its component. During high polluted episodes the local

487 contributions do not increase and the increase of PM and related sources can be addresses to

488 external contribution.

489

490

491

492

493

494

495

\section{Conclusions}

The knowledge of ground-wind circulation and potential long-range transports is fundamental to evaluate how and how much local or external sources may affect the air quality at a receptor site. In this study, the results of a recent source apportionment study carried out in Venice (Eastern Po Valley) are used as input for different statistical approaches. Meteorology-based methods (backtrajectories and wind-based methods) have been used to determine the influence of external and local contribution on identified $\mathrm{PM}_{2.5}$ sources.

About applied methodologies some consideration can be done:

- Cluster on back-trajectories represents an easy but effective method to evaluate the potential effects of long-range/regional transports. It helps in understanding the area of origin but does not provide a precise location.

- Generally, PSCF and CWT analyses return very similar results to cluster but they give some more clues about the potential source location.

- Despite CWT distributes concentration along the trajectories similarly to PSCF, this method has an advantage: it distinguishes major sources from moderate ones by calculating concentration gradients and it becomes more effective in estimating of external contributions.

- Cluster on wind data partially help in understanding the source locations respect to each sampling site. The analysis can be affected to widespread pollution condition and the wind speed component tends to dominates in the interpretations of results respect to direction.

- The application of CPF provides understanding of the most probable sources location, with the highest probability associated to the local sources respect to the external ones (e.g. road traffic).

- Lenschow's approach represents a useful method to estimate local contribution but it requires to have a good knowledge of the study area and its emission sources and more than one measurement sites at least one of these considerable as a background site. This may be a limitation to its applicability. 
Obtained results highlighted the complexity of atmospheric dynamics in the study area and our influence on PM and sources levels: (i) external contributions are a not negligible intake of $\mathrm{PM}_{2.5}$ and (ii) local atmospheric circulation determines different levels of source contribution and some specific direction have been detected.

PM sources contributions are influenced by external contribution coming mainly from Po Valley and East-Europe. Seasonally, high external contribution can be observed during spring and winter reaching $40 \mu \mathrm{g} \mathrm{m}^{-3}$ and $30 \mu \mathrm{g} \mathrm{m}^{-3}$ for $\mathrm{PM}_{2.5}$ and ammonium nitrate, respectively. Moreover, the external contributions of ammonium sulphate, that represent the second PM mass source, reach 14 $\mu \mathrm{g} \mathrm{m}^{-3}$ during autumn and winter over East-Europe.

Among the identified sources, industrial, ammonium nitrate and fossil fuel combustion appear more sensitive to local atmospheric circulation changes. In particular, fossil fuels contribution enhance in days characterized by wind blowing from SE while industrial and ammonium nitrate levels are most affected by the different wind speed. Other sources do not show a strong dependence on the wind direction.

Lenschow's approach has allowed to estimate the local contribution on PM and its sources: yearly, local sources contribute for $9.8 \mu \mathrm{g} \mathrm{m}^{-3}$ of $\mathrm{PM}_{2.5}$ amounting to $28 \%$ and $30 \%$ of masses in URB and IND site, respectively. During heavy PM events the local contribution percentage are similar to the average conditions ( $28.4 \%$ and $27.7 \%$, respectively), hence the increase of PM and related sources can be mainly addresses to external contribution. Only fossil fuels represent an exception: during these events the local contribution reaches the $56 \%$ and the $63 \%$ in URB and IND, respectively, about twice the average percentage of samples.

\section{Acknowledgment}

The authors would like to thanks Ente Zona Industriale di Porto Marghera (http://www.entezona.it/) for the financial support to the project "Study of secondary particulate matter in the Venice area", ARPAV and Comando Zona Fari e Segnalamenti Marittimi di Venezia for logistics.

The authors gratefully acknowledge the NOAA Air Resources Laboratory (ARL) for providing the HYSPLIT transport and dispersion model and access to READY website (http://ready.arl.noaa.gov).

\section{REFERENCES}

Ashbaugh, L. L., Malm, W. C., and Sadeh, W. Z., 1985. A Residence Time Probability Analysis of Sulfur Concentrations at Ground Canyon National Park. Atmos. Environ. 19(8), 1263-1270.

ARPAV, 2011. Air quality in Venice, Annual report 2010. In Italian, available at: http://www.arpa.veneto.it/arpav/chi-e-arpav/file-e-allegati/dap-venezia/aria/RQA2010.pdf. 
Brereton, C.A., Johnson, M.R., 2012. Identifying sources of fugitive emissions in industrial facilities using trajectory statistical methods. Atmos. Environ. 51, 46-55.

Carslaw D.C., Beevers S.D., Ropkins K., Bell M.C., 2006. Detecting and quantifying aircraft and other on-airport contributions to ambient nitrogen oxides in the vicinity of a large international airport. Atmos. Environ. 40, 5424-5434.

CEN (Comité Européen de Normalisation), 2005. Ambient air quality — standard gravimetric measurements for the determination of the PM2.5 mass fraction of suspended particulate matter. EN 14907:2005.

Cesari D., Genga, A., Ielpo, P., Siciliano, M., Mascolo, G., Grasso, F. M., Contini, D., 2014. Source apportionment of $\mathrm{PM}_{2.5}$ in the harbour-industrial area of Brindisi (Italy): Identification and estimation of the contribution of in-port ship emissions. Sci. Total Environ. 497-498, 392400 .

Cheng, I., Zhang, P., Blanchard, P., Dalziel, J., Tordon, R., 2013. Concentration-weighted trajectory approach to identifying potential sources of speciated atmospheric mercury at an urban coastal site in Nova Scotia, Canada. Atmos. Chem. Phys. 13, 6031-6048.

Darby, L., 2005. Cluster analysis of surface winds in Houston, Texas, and the impact of wind patterns on ozone. J. Appl. Meteorol. 44, 1788-1806.

Draxler R.R., Rolph G.D., 2015. HYSPLIT (HYbrid Single-Particle Lagrangian Integrated Trajectory) Model access via NOAA ARL READY Website (http://www.arl.noaa.gov/HYSPLIT.php). NOAA Air Resources Laboratory, College Park, MD.

Dvorska, A., Lammel, G., Klanova, J., Holoubek, I., 2008. Kosetice, Czech Republic - ten years of air pollution monitoring and four years of evaluating the origin of persistent organic pollutants. Environ. Pollut. 156, 403-408.

EEA (European Environment Agency), 2015. AirBasedThe European Air Quality Database. Available from: http://www.eea.europa.eu/themes/air/air-quality/map/airbase (last accessed February, 2015).

Fleming Z.L., Monks P.S., Manning A.J., 2012. Review: Untangling the influence of air-mass history in interpreting observed atmospheric composition. Atmos. Res. 104-105, 1-39.

Gilardoni, S., Vignati, E., Cavalli, F., Putaud, J. P., Larsen, B. R., Karl, M., Stenström, K., Genberg, J., Henne, S., 2011. Better constraints on sources of carbonaceous aerosols using a combined $14 \mathrm{C}$ - macro tracer analysis in a European rural background site. Atmos. Chem. Phys. 11, 5685-5700.

Gildemeister, A. E., Hopke, P. K., Kim, E., 2007. Sources of fine urban particulate matter in Detroit, MI. Chemosphere 69, 1064-1074.

Han, Y.-J., Holsen, T. M., and Hopke, P. K., 2007. Estimation of source locations of total gaseous mercury measured in New York State using trajectory-based models. Atmos. Environ. 41, 6033-6047. 
Hopke, P.K., Li, C.L., Ciszek, W., Landsberger, S., 1995. The use of bootstrapping to estimate conditional probability fields for source locations of airborne pollutants. Chemometr. Intell. Lab. 30, 69-79.

Hsu, Y., Holsen, T.M., Hopke, P.K., 2003. Comparison of hybrid receptor models to locate PCB sources in Chicago. Atmos. Environ. 37, 545-562.

Kabashnikov, V. P., Chaikovsky, A. P., Kucsera, T. L., and Metelskaya, N. S., 2011. Estimated accuracy of three common trajectory statistical methods. Atmos. Environ. 45, 5425-5430.

Kaufmann, P., Whiteman, C.D., 1999. Cluster-analysis classification of wintertime wind patterns in the Grand Canyon region. J. Appl. Meteorol. 38, 1131-1147.

Kim, E., Hopke, P.K., Edgerton, E.S., 2003. Source Identification of Atlanta Aerosol by Positive Matrix Factorization. J. Air Waste Manage. Assoc. 53, 731-739.

Kim, E., Hopke, P. K., 2004. Comparison between Conditional Probability Function and Nonparametric Regression for Fine Particle Source Directions. Atmos. Environ. 38, 4667 4673.

Kim, E., Hopke, P.K., Kenski, D.M., Koerber, M., 2005. Sources of Fine Particles in a Rural Midwestern U.S. Area. Environ. Sci. Technol. 39, 4953-4960.

Kundu S., Kawamura, K., Andreae TW., Hoffer A., Andreae M.O., 2010. Diurnal variation in the water-soluble inorganic ions, organic carbon and isotopic compositions of total carbon and nitrogen in biomass burning aerosols from the LBA-SMOCC campaign in Rondônia, Brazil. J.Aerosol Sci. 41, 118-133.

Larsen, B. R., Gilardoni, S., Stenström, K., Niedzialek, J., Jimenez, J., Belis, C. A., 2012. Sources for PM air pollution in the Po Plain, Italy: II. Probabilistic uncertainty characterization and sensitivity analysis of secondary and primary sources. Atmos. Environ. 50, 203-213.

Lee, J.H., Hopke, P.K., 2006. Apportioning sources of PM2.5 in St. Louis, MO using speciation trends network data. Atmos. Environ. 40, 360-377.

Lenschow, P., Abraham, H.-J., Kutzner, K., Lutz, M., Preuß, J.-D., Reichenbächer, W., 2001. Some ideas about the sources of PM10. Atmos. Environ. 35, S23-S33.

Lim, J.-M., Lee, J.-H., Moon, J.-H., Chung, Y.-S., Kim, K.-H., 2010. Airborne PM10 and metals from multifarious sources in an industrial complex area. Atmos. Res. 96, 53-64.

Lupu, A., Maenhaut, W., 2002. Application and comparison of two statistical trajectory techniques for identification of source regions of atmospheric aerosol species. Atmos. Environ. 36, 56075618.

Masiol, M., Rampazzo, G., Ceccato, D., Squizzato, S., Pavoni B., 2010. Characterization of PM10 sources in a coastal area near Venice (Italy): An application of factor-cluster analysis. Chemosphere 80, 771-778.

Masiol M., Squizzato S., Ceccato D., Rampazzo G., Pavoni B., 2012a. Determining the influence of different atmospheric circulation patterns on PM10 chemical composition in a source apportionment study. Atmos. Environ. 63, 117-124.

Masiol, M., Centanni, E., Squizzato, S., Hofer, A., Pecorari, E., Rampazzo, G., Pavoni, B., 2012 b. GC-MS analyses and chemometric processing to discriminate the local and long-distance 
sources of PAHs associated to atmospheric PM2.5. Environ. Sci. Pollut. Res. 19 (8), 3142 3151.

Masiol, M., Squizzato, S., Rampazzo, G., Pavoni, B., 2014b. Source apportionment of PM2.5 at multiple sites in Venice (Italy): Spatial variability and the role of weather. Atmos. Environ. $98,78-88$.

Masiol M., Benetello F., Harrison R.M., Formenton G., De Gaspari F., Pavoni B., 2015. Spatial, seasonal trends and transboundary transport of PM2.5 inorganic ions in the Veneto Region (Northeast Italy). Atmos. Environ. 117, 19-31.

Maurizi, A., Russo, F., Tampieri, F., 2013. Local vs. external contribution to the budget of pollutants in the Po Valley (Italy) hot spot. Sci. Total Environ. 458-460, 459-465.

Moreno, T., Querol, X., Alastuey, A., Viana, M., Salvador, P., Sanchez de la Campa, A., Artiñano, B., de la Rosa J., Gibbons, W., 2006. Variation in atmospheric PM trace metal content in Spanish towns: illustrating the chemical complexity of the inorganic urban aerosol cocktail. Atmos. Environ. 40, 6791-6803.

Pekney, N. J., Davidson, C. I., Zhou, L., Hopke, P. K., 2006. Application of PSCF and CPF to PMF-Modeled Sources of PM2.5 in Pittsburgh. Aerosol Sci. Technol. 40, 952-961.

Putaud, J.-P., Van Dingenen, R., Alastuey, A., Bauer, H., Birmili, W., Cyrys, J., Flentje, H., Fuzzi, S., Gehrig, R., Hansson, H.C., Harrison, R.M., Herrmann, H., Hitzenberger, R., Hüglin, C., Jones, A.M., Kasper-Giebl, A., Kiss, G., Kousa, A., Kuhlbusch, T.A.J., Löschau, G., Maenhaut, W., Molnar, A., Moreno, T., Pekkanen, J., Perrino, C., Pitz, M., Puxbaum, H., Querol, X., Rodriguez, S., Salma, I., Schwarz, J., Smolik, J., Schneider, J., Spindler, G., ten Brink, H., Tursic, J., Viana, M., Wiedensohler, A., Raes, F., 2010. A European aerosol phenomenology - 3: Physical and chemical characteristics of particulate matter from 60 rural, urban, and kerbside sites across Europe. Atmos. Environ. 44, 1308-1320.

Rolph, G.D., 2015. Real-time Environmental Applications and Display sYstem (READY) Website (http://www.ready.noaa.gov). NOAA Air Resources Laboratory, College Park, MD.

Rutter, A. P., Snyder, D. C., Stone, E. A., Schauer, J. J., Gonzalez-Abraham, R., Molina, L. T., Márquez, C., Cárdenas, B., and de Foy, B., 2009. In situ measurements of speciated atmospheric mercury and the identification of source regions in the Mexico City Metropolitan Area. Atmos. Chem. Phys. 9, 207-220.

Salameh, D., Detournay, A, Pey, J., Pérez, N., Liguori, F., Saraga, D., Bove, M. C., Brotto, P., Cassola, F., Massabò, D., Latella, A., Pillon, S., Formenton, G., Patti, S., Armengaud, A., Piga, D., Jaffrezo, J., Bartzis, J., Tolis, E., Prati, P., Querol, X., Wortham, H., Marchand, N., 2015. $\mathrm{PM}_{2.5}$ chemical composition in five European Mediterranean cities: A 1-year study. Atmos. Res. 155, 102-117.

Seibert, P., Kromp-Kolb, H., Baltensperger, U., Jost, D.T., Schwikowski, M., Kasper, A., Puxbaum, H., 1994. Trajectory analysis of aerosol measurements at high alpine sites. In: Borrell, P.M., Borrell, P., Cvitas, T., Seiler, W. (Eds.), Transport and Transformation of Pollutants in the Troposphere, Academic Publishing, Den Haag (1994), pp. 689-693. 
Squizzato, S., Masiol, M., Innocente, E., Pecorari, E., Rampazzo, G., Pavoni, B., 2012. A procedure to assess local and long-range transport contributions to PM2.5 and secondary inorganic aerosol. J. Aerosol Sci. 46, 64-76.

Squizzato, S., Masiol, M., Visin, F., Canal, A., Rampazzo, G., Pavoni, B., 2014. PM2.5 chemical composition in an industrial zone included in a large urban settlement: main sources and local background. Environ. Sci. Proc. Impacts 16(8), 1913-1922.

Spencer M.T., Shields L.G., Sodeman D.A., Toner S.M., Prather K.A., 2006. Comparison of oil and fuel particle chemical signatures with particle emissions from heavy and light duty vehicles. Atmos. Environ. 40, 5224-5235

Stohl, A., 1998. Computation, accuracy and applications of trajectories- review and bibliography. Atmos. Environ. 32, 947-966.

Uria-Tellaetxe I., Carslaw D.C., 2014. Conditional bivariate probability function for source identification. Environ. Model. Softw. 59 1-9.

Viana M., Querol X., Alastuey A., Gil J.I., Menéndez M., 2006. Identification of PM sources by principal component analysis (PCA) coupled with wind direction data. Chemosphere 65, 2411-2418.

Wehrens, R., Putter, H., Buydens, L.M.C., 2000. The bootstrap: a tutorial. Chemometr. Intell. Lab $54,35-52$.

Weiss-Penzias, P. S., Gustin, M. S., and Lyman, S. N., 2011. Sources of gaseous oxidized mercury and mercury dry deposition at two southeastern U.S. sites. Atmos. Environ. 45, 4569-4579.

Table captions

Table 1. Average concentrations $\left(\mu \mathrm{g} \mathrm{m}^{-3}\right)$ and percentage difference respect to all samples mean $(\Delta \%)$ in SRB samples of $\mathbf{P M}_{2.5}$ and source contributions for each identified back-trajectories cluster.

Table 2. Local contribution expressed in $\mu \mathrm{g} \mathrm{m}^{-3}$ and \% estimated using Lenschow' approach for URB and IND site.

Figure captions

Fig. 1. Sampling site locations (a), gridded back trajectory frequencies (b) and backtrajectories clusters (c).

Fig. 2. PSCF probabilities for $\mathrm{PM}_{2.5}$ and identified sources $\left(75^{\text {th }}\right.$ percentile).

Fig. 3a. CWT for $\mathrm{PM}_{2.5}$, ammonium nitrate and ammonium sulphate sources.

Fig. 3b. CWT for industrial, traffic, glassmaking and fossil fuel combustion sources.

Fig. 4. Results of cluster analysis on wind data: box-plots and wind roses for each identified cluster $(\mathrm{Chs}=$ wind calm hours; Ws = average wind speed $)$. Boxes represent inter-quartile 

ranges).

Fig. 5. CPF plots for the highest $25 \%$ of the mass contributions.

708

709 
Table 1. Average concentrations $\left(\mu \mathrm{g} \mathrm{m}^{-3}\right)$ and percentage difference respect to all samples mean $(\Delta \%)$ in $\mathrm{SRB}$ samples of $\mathrm{PM}_{2.5}$ and source contributions for each identified back-trajectories cluster.

\begin{tabular}{|c|c|c|c|c|c|c|c|c|c|c|c|c|c|c|}
\hline & \multicolumn{2}{|l|}{$\mathrm{PM}_{2.5}$} & \multicolumn{2}{|c|}{ Industrial } & \multicolumn{2}{|c|}{ Fossil fuels } & \multicolumn{2}{|c|}{ Amm. Nitrate } & \multicolumn{2}{|c|}{ Glass-making } & \multicolumn{2}{|c|}{ Amm. Sulfate } & \multicolumn{2}{|c|}{ Road traffic } \\
\hline & Mean & $\Delta(\%)$ & Mean & $\Delta(\%)$ & Mean & $\Delta(\%)$ & Mean & $\Delta(\%)$ & Mean & $\Delta(\%)$ & Mean & $\Delta(\%)$ & Mean & $\Delta(\%)$ \\
\hline Atlantic $(\mathrm{N}=7)$ & 23.6 & -5 & 3.1 & -13 & 2.2 & 15 & 15.8 & 35 & 1.6 & 57 & 1.0 & -83 & 0.2 & -75 \\
\hline Central EU (N=18) & 16.2 & -35 & 2.9 & -21 & 2.1 & 11 & 7.8 & -33 & 0.7 & -30 & 2.2 & -62 & 0.6 & -16 \\
\hline Northern EU (N=14) & 15.6 & -37 & 2.4 & -34 & 1.1 & -45 & 9.0 & -24 & 0.8 & -27 & 2.0 & -66 & 0.4 & -32 \\
\hline East - Austria $(\mathrm{N}=42)$ & 26.4 & 7 & 4.5 & 24 & 1.7 & -10 & 12.0 & 2 & 1.4 & 33 & 6.1 & 2 & 0.9 & 35 \\
\hline Eastern EU (N=21) & 34.6 & 40 & 5.8 & 62 & 0.9 & -54 & 12.5 & 7 & 1.2 & 18 & 13.4 & 124 & 0.9 & 39 \\
\hline South $(\mathrm{N}=37)$ & 25.0 & 1 & 2.3 & -36 & 3.1 & 60 & 12.3 & 5 & 0.8 & -26 & 6.3 & 5 & 0.5 & -23 \\
\hline Western MED $(\mathrm{N}=15)$ & 24.9 & 1 & 3.4 & -5 & 1.5 & -24 & 13.7 & 17 & 0.8 & -21 & 5.1 & -14 & 0.6 & -11 \\
\hline All samples & 24.7 & & 3.6 & & 1.9 & & 11.7 & & 1.0 & & 6.0 & & 0.7 & \\
\hline
\end{tabular}


Table 2. Local contribution expressed in $\mu \mathrm{g} \mathrm{m}^{-3}$ and \% estimated using Lenschow' approach for URB and IND site.

\begin{tabular}{|c|c|c|c|c|c|c|c|c|c|c|c|c|c|c|}
\hline & \multicolumn{2}{|c|}{$\mathrm{PM}_{\text {local }}$} & \multicolumn{2}{|c|}{ Industrial local } & \multicolumn{2}{|c|}{ Fossil local } & \multicolumn{2}{|c|}{ Amm. nitrate ${ }_{\text {local }}$} & \multicolumn{2}{|c|}{ Glass $_{\text {local }}$} & \multicolumn{2}{|c|}{ Amm. sulfate ${ }_{\text {local }}$} & \multicolumn{2}{|c|}{ Traffic ${ }_{\text {local }}$} \\
\hline & $\mu \mathrm{g} \mathrm{m}^{-3}$ & $\%$ & $\mu \mathrm{g} \mathrm{m}^{-3}$ & $\%$ & $\mu \mathrm{g} \mathrm{m}^{-3}$ & $\%$ & $\mu \mathrm{g} \mathrm{m}^{-3}$ & $\%$ & $\mu \mathrm{g} \mathrm{m}^{-3}$ & $\%$ & $\mu \mathrm{g} \mathrm{m}^{-3}$ & $\%$ & $\mu \mathrm{g} \mathrm{m}^{-3}$ & $\%$ \\
\hline \multicolumn{15}{|l|}{ Via Lissa (URB) } \\
\hline All samples & 9.8 & 27.7 & 2.5 & 40.0 & 1.3 & 34.8 & 5.6 & 31.0 & 1.2 & 58.8 & 1.0 & 25.6 & 5.2 & 82.8 \\
\hline Spring & 11.3 & 26.3 & 2.5 & 52.2 & 1.2 & 32.0 & 6.2 & 20.5 & 1.6 & 67.7 & 1.8 & 39.0 & 5.0 & 86.9 \\
\hline Summer & 4.5 & 31.2 & 1.7 & 32.5 & 1.4 & 32.2 & 0.8 & & 1.2 & 59.3 & 0.5 & 20.1 & 2.5 & 76.3 \\
\hline Autumn & 5.7 & 24.5 & 1.6 & 42.9 & 1.6 & 43.2 & 4.5 & 50.3 & 1.1 & 64.3 & 0.7 & 23.9 & 6.9 & 84.7 \\
\hline Winter & 15.5 & 28.6 & 3.3 & 31.8 & 0.2 & 42.5 & 5.9 & 30.1 & 1.1 & 44.4 & 1.2 & 25.7 & 5.1 & 81.2 \\
\hline Heavy PM Events $\left(>75^{\text {th }}\right.$ percentile) & 20.4 & 28.4 & 4.4 & 41.8 & 2.5 & 56.3 & 7.9 & 24.6 & 1.3 & 51.7 & 1.8 & 19.1 & 6.1 & 80.9 \\
\hline \multicolumn{15}{|l|}{ Malcontenta (IND) } \\
\hline All samples & 9.8 & 29.9 & 4.6 & 53.8 & 1.9 & 54.6 & 5.1 & 34.0 & 1.1 & 57.5 & 1.3 & 31.3 & 3.4 & 74.3 \\
\hline Spring & 10.4 & 31.7 & 4.9 & 69.3 & 2.0 & 46.1 & 6.3 & 36.7 & 1.4 & 69.5 & 1.8 & 42.8 & 5.1 & 91.3 \\
\hline Summer & 8.9 & 40.5 & 3.7 & 52.8 & 1.9 & 40.0 & 3.6 & 55.2 & 1.3 & 67.3 & 0.5 & 28.3 & 0.6 & 58.5 \\
\hline Autumn & 6.6 & 25.4 & 3.1 & 48.2 & 2.3 & 64.4 & 2.3 & 39.9 & 0.5 & 44.0 & 1.5 & 33.0 & 3.5 & 75.2 \\
\hline Winter & 12.5 & 24.8 & 5.9 & 48.4 & 1.1 & 81.9 & 5.6 & 28.2 & 0.8 & 38.0 & 1.4 & 26.6 & 2.9 & 66.9 \\
\hline Heavy PM Events ( $>75^{\text {th }}$ percentile) & 17.6 & 27.2 & 6.9 & 46.0 & 1.8 & 62.6 & 6.0 & 26.4 & 0.9 & 41.8 & 1.5 & 20.8 & 3.6 & 66.4 \\
\hline
\end{tabular}




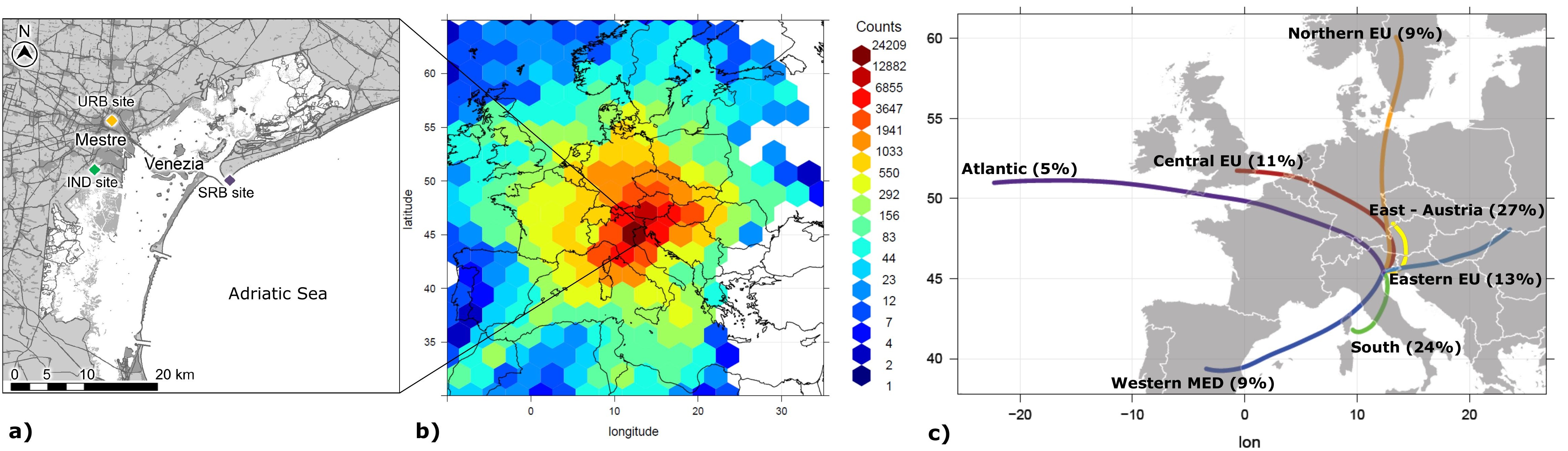


$\mathrm{PM}_{2.5}$

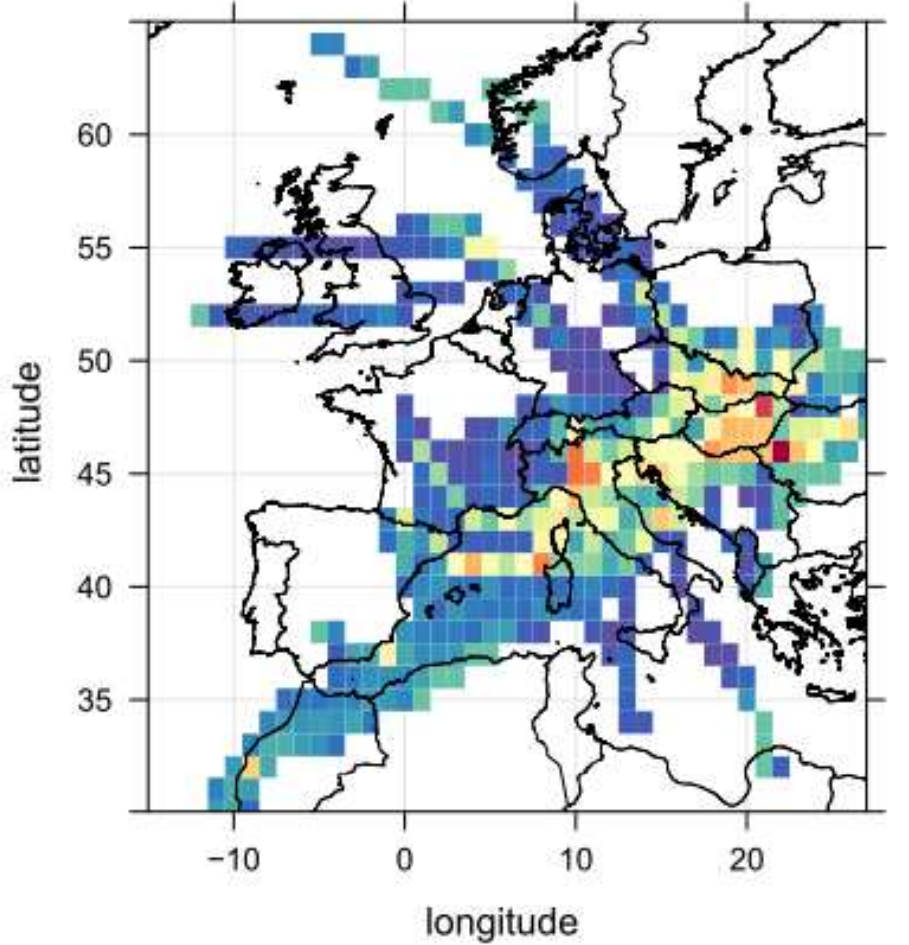

\section{PSCF probability}

Industrial

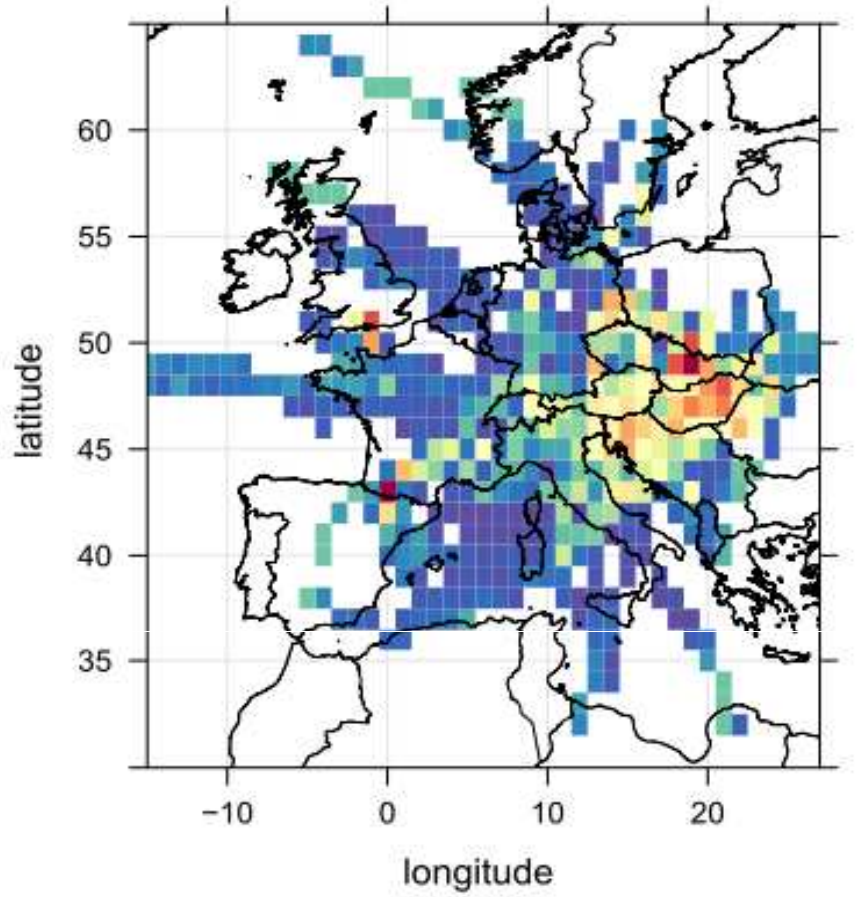

\section{Ammonium sulfate}

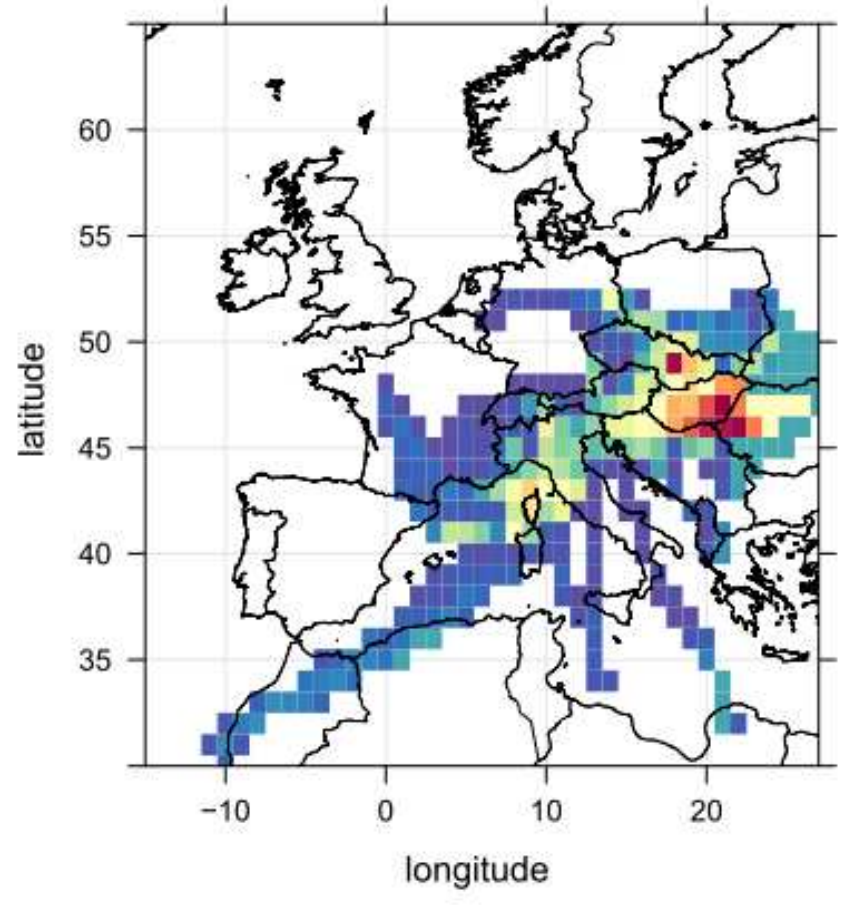

Fossil fuels

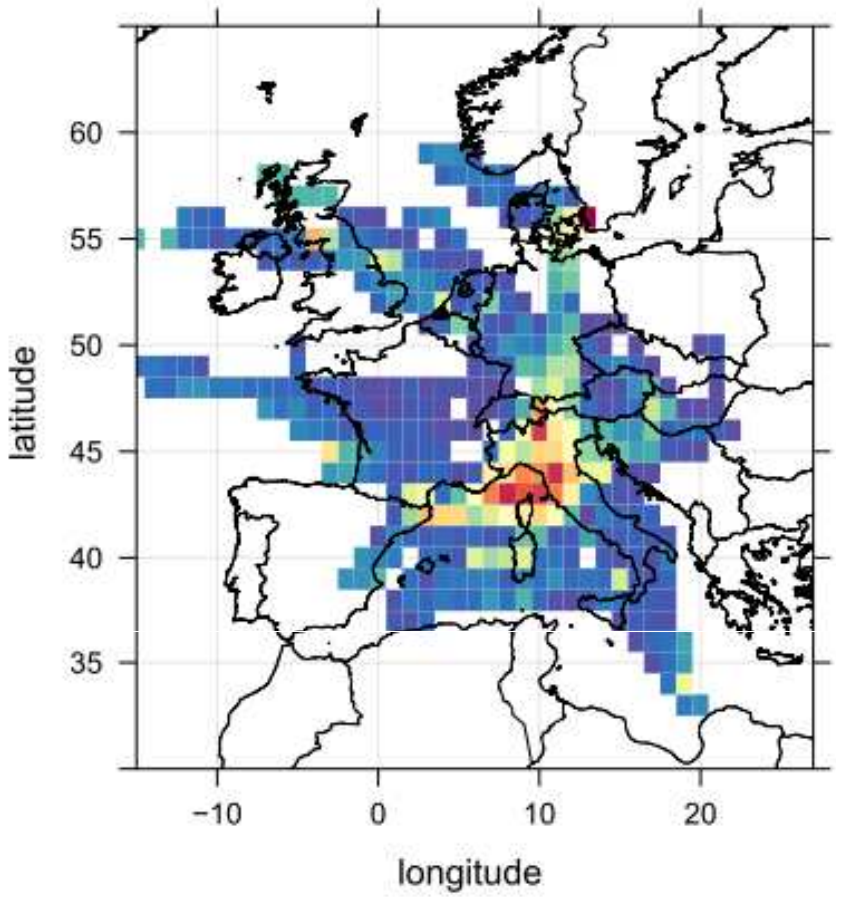

Glass-making

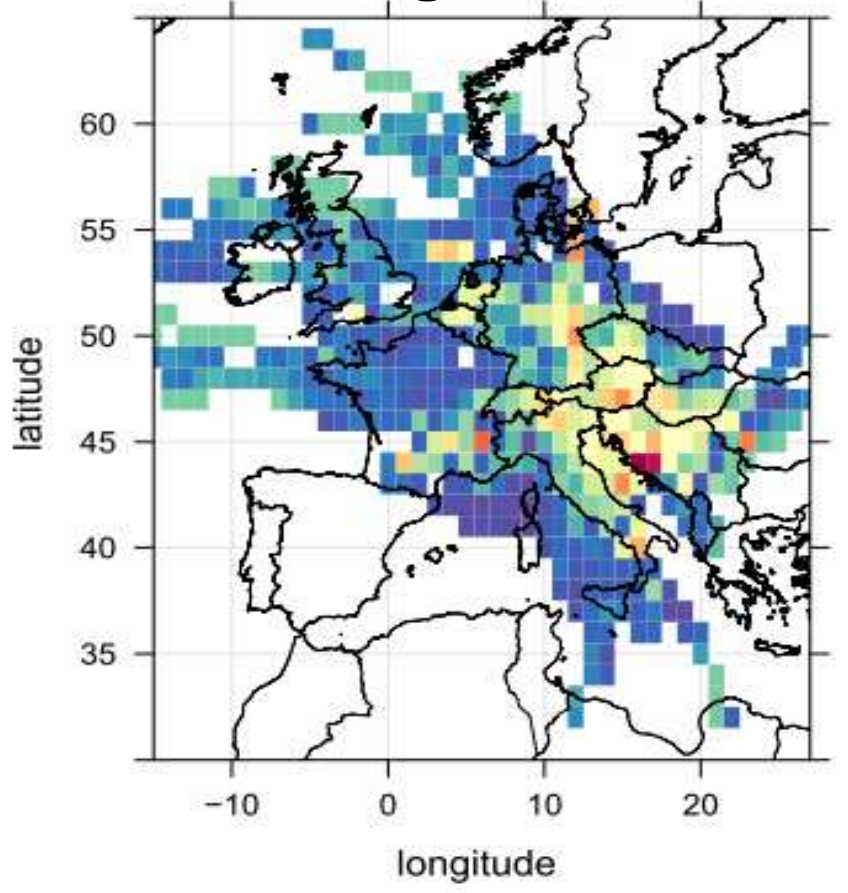

$\begin{array}{llllll}0.1 & 0.2 & 0.3 & 0.4 & 0.5 & 0.6\end{array}$

Ammonium nitrate

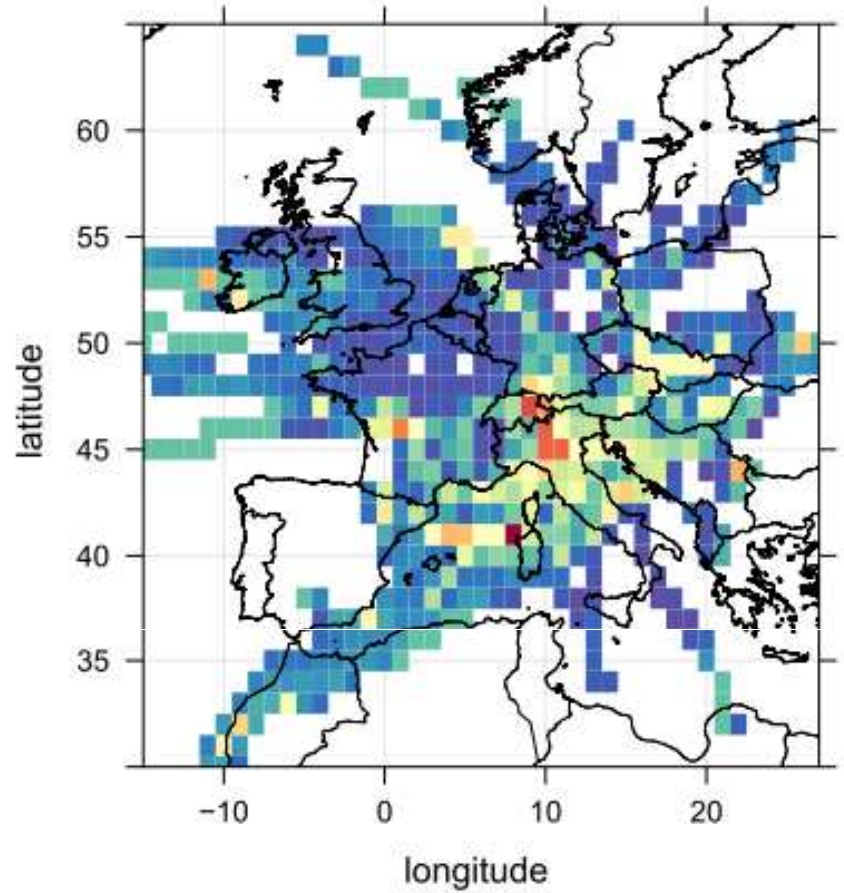

Traffic

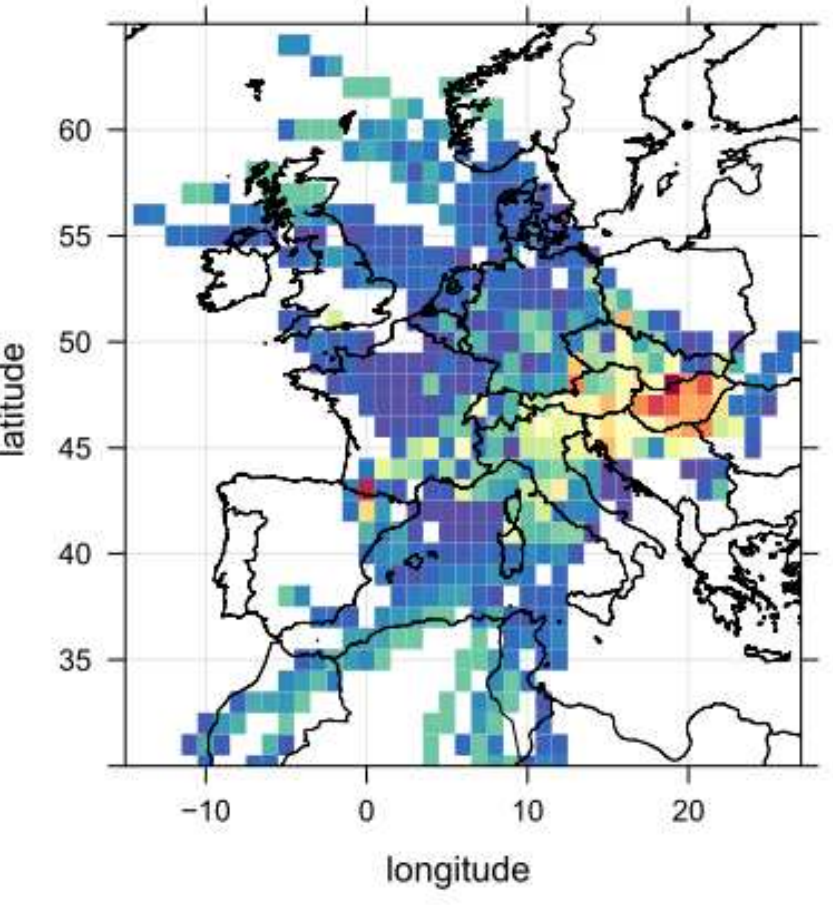




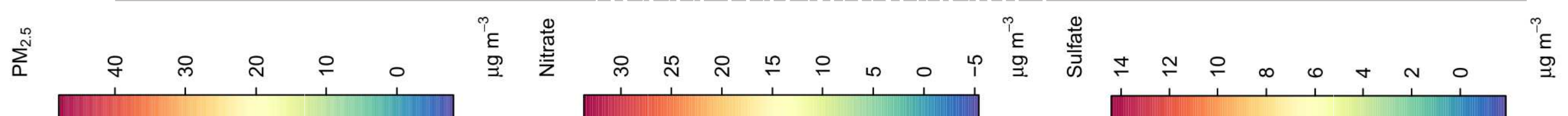

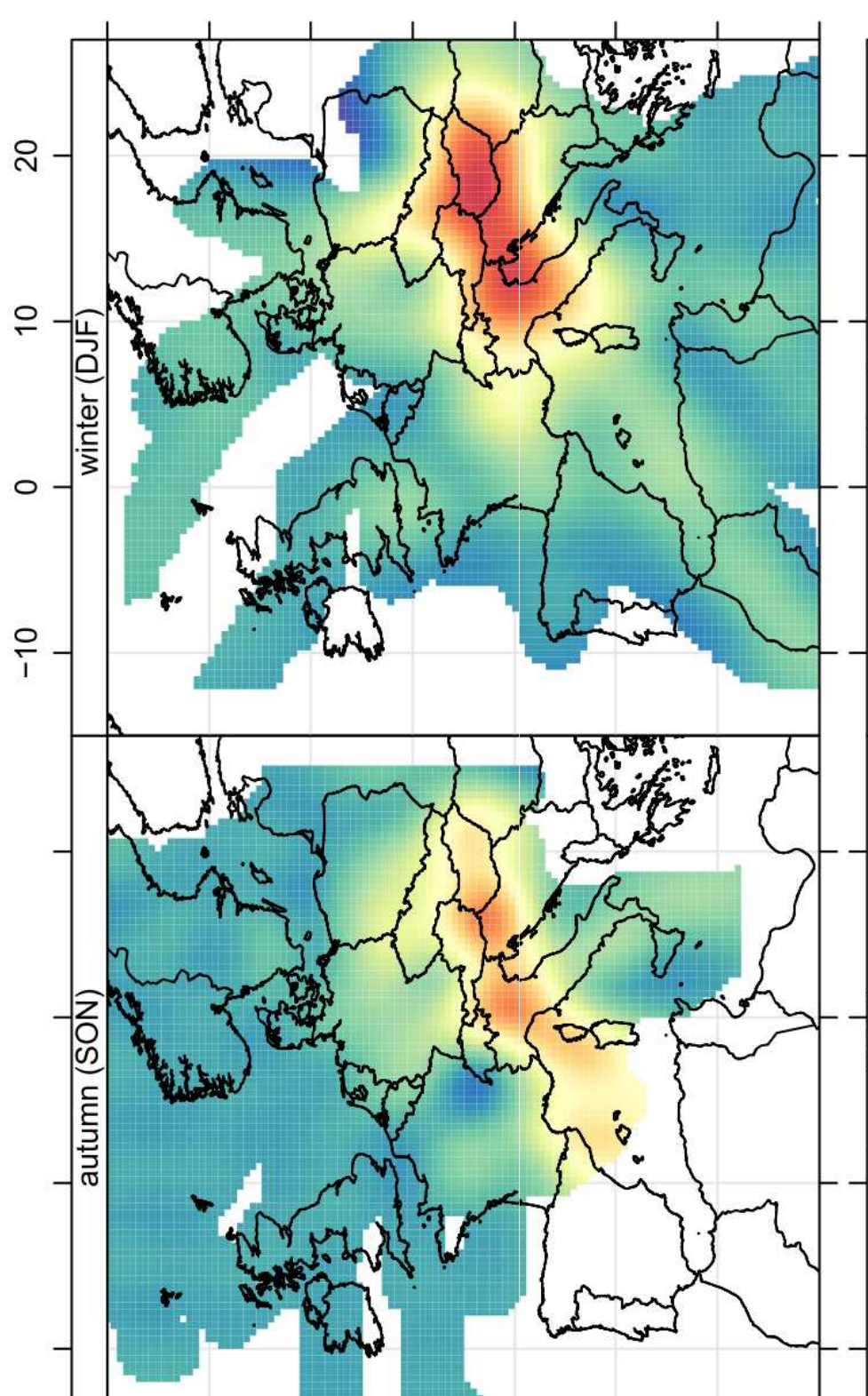

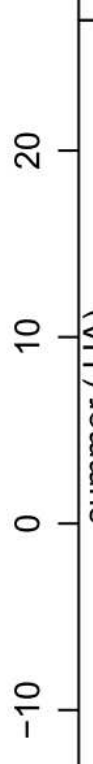

Whe min

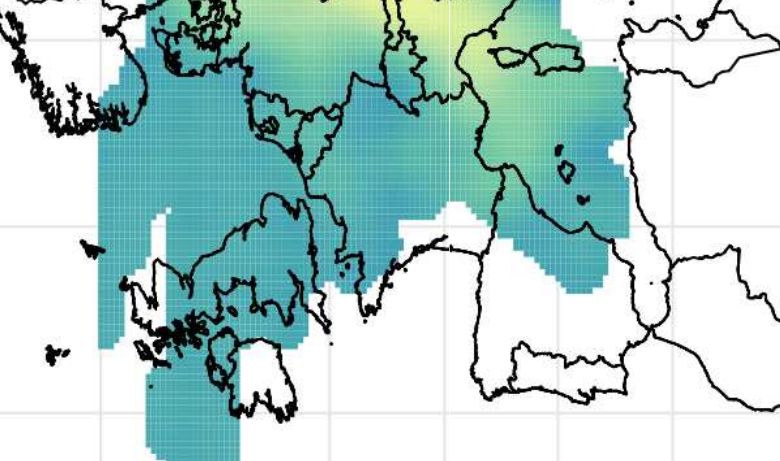

in

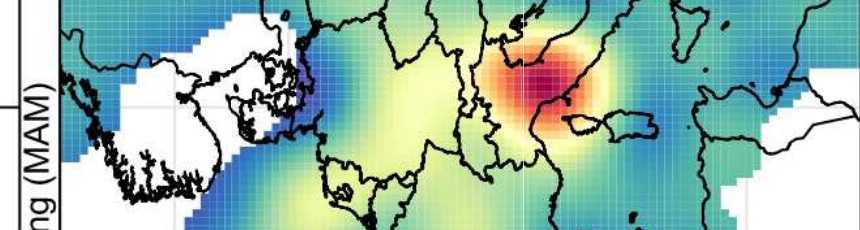

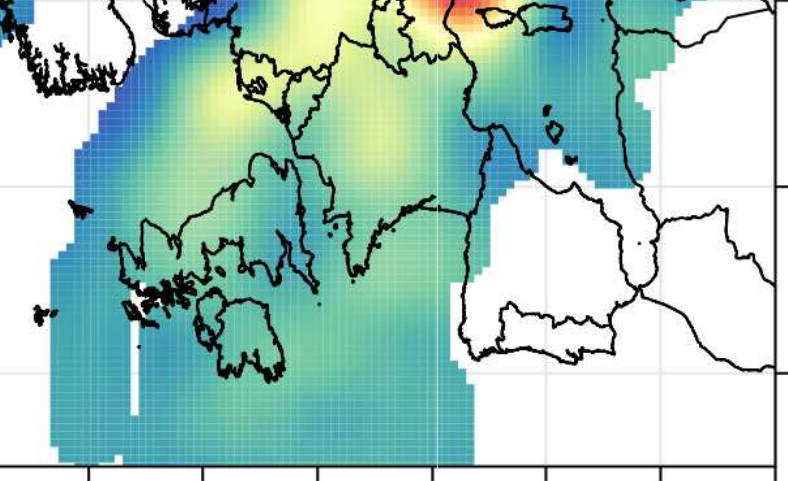

8 员 品 \& \&

әрпџ!ฺอ|
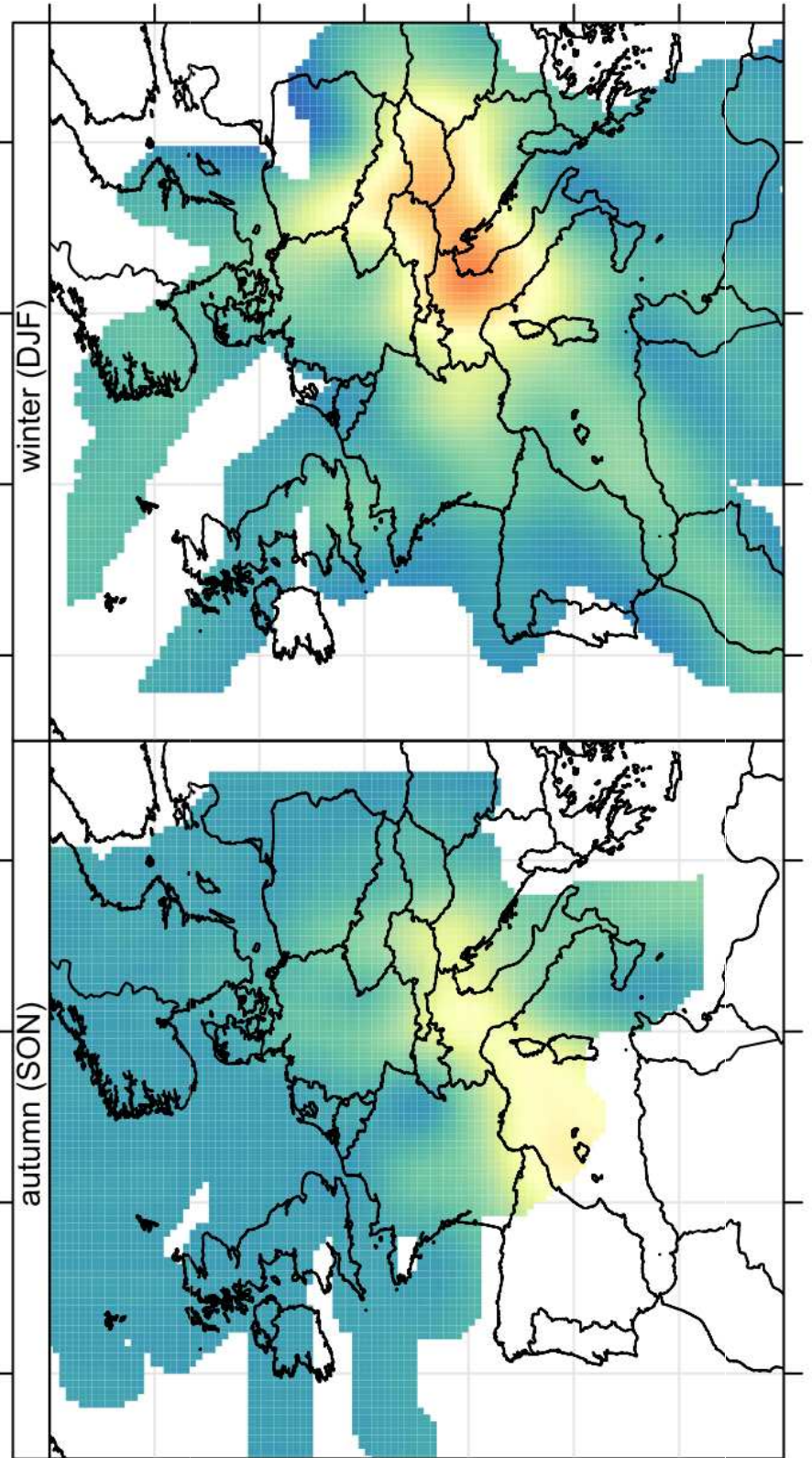

(3)

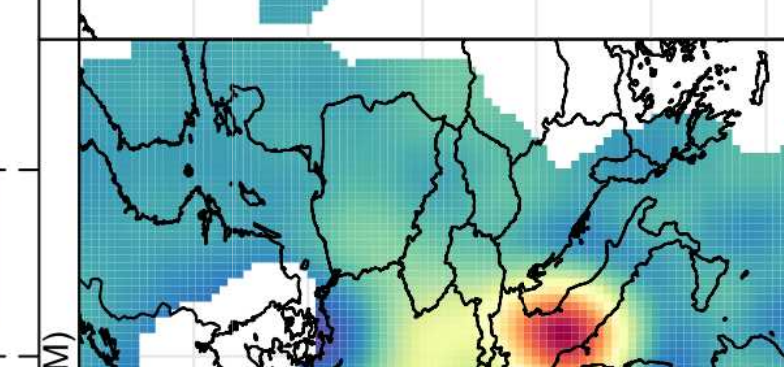

(n)

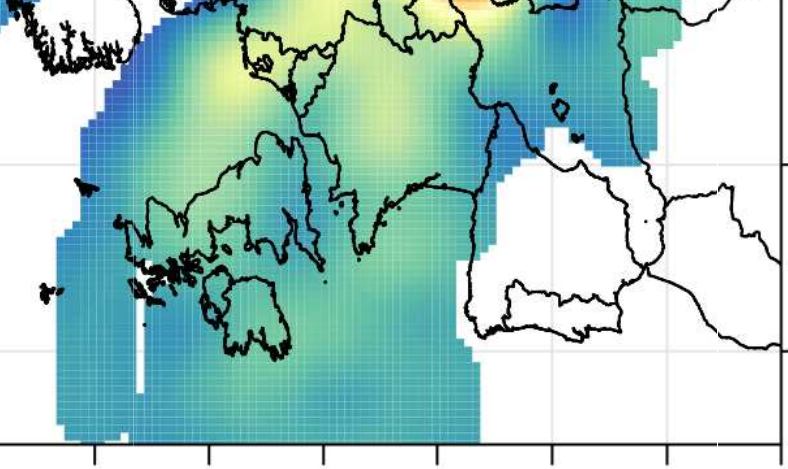

용요 웅 点

әрп!ฺฺ|
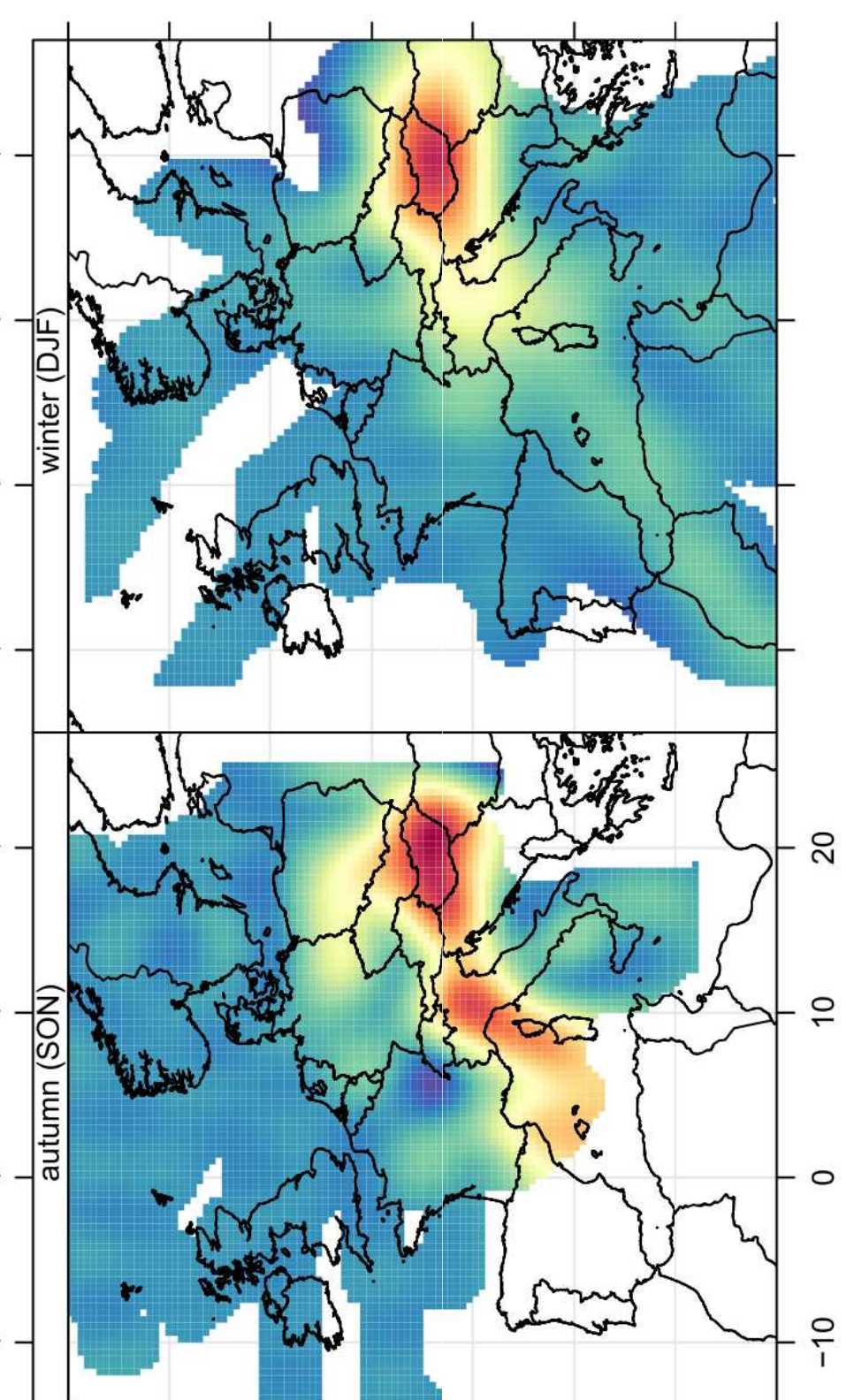

from 
ALL: full period
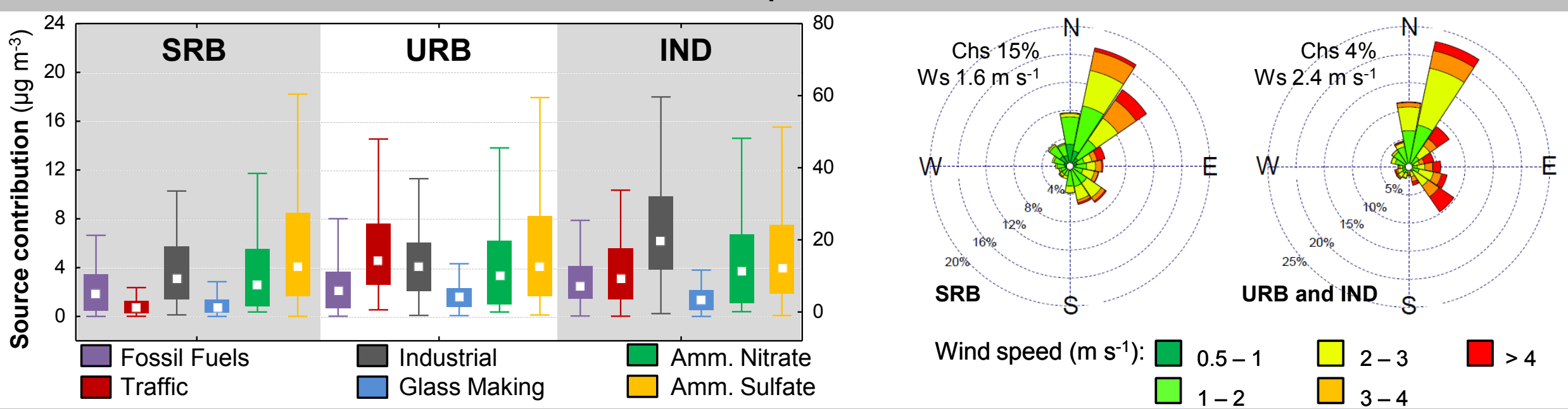

Group 1
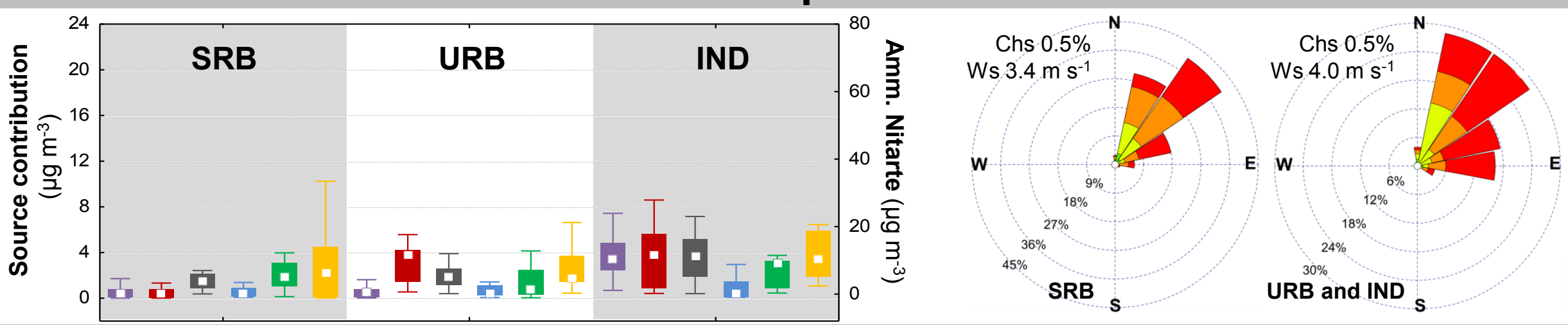

\section{Group 2}

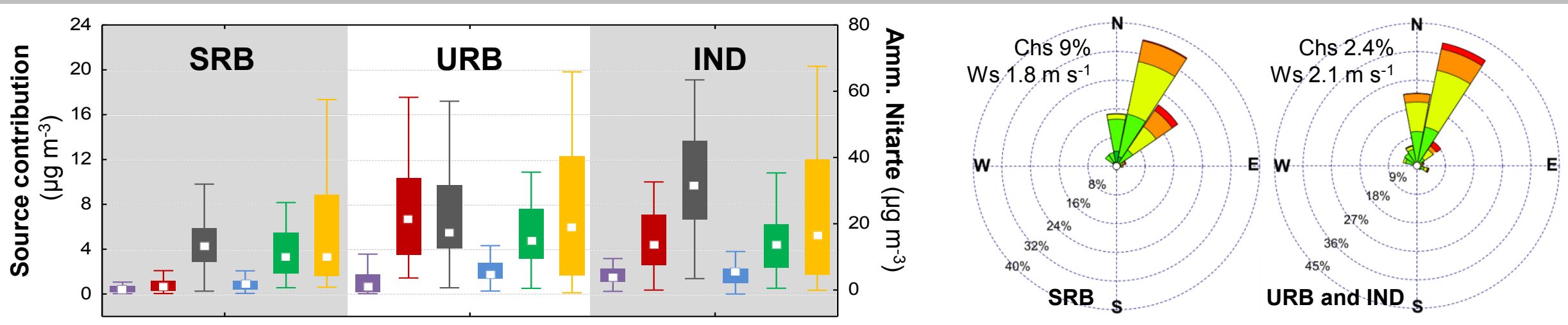

\section{Group 3}
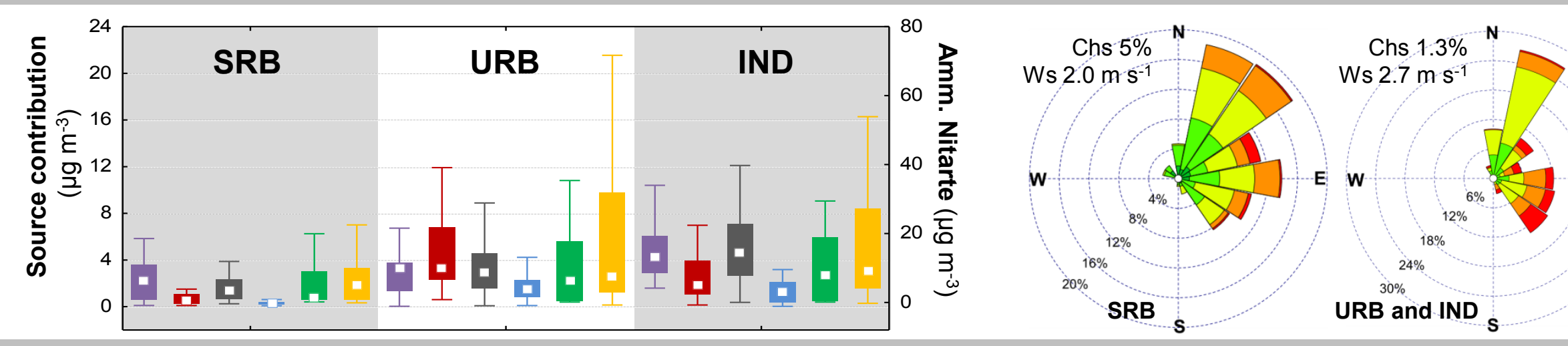

\section{Group 4}

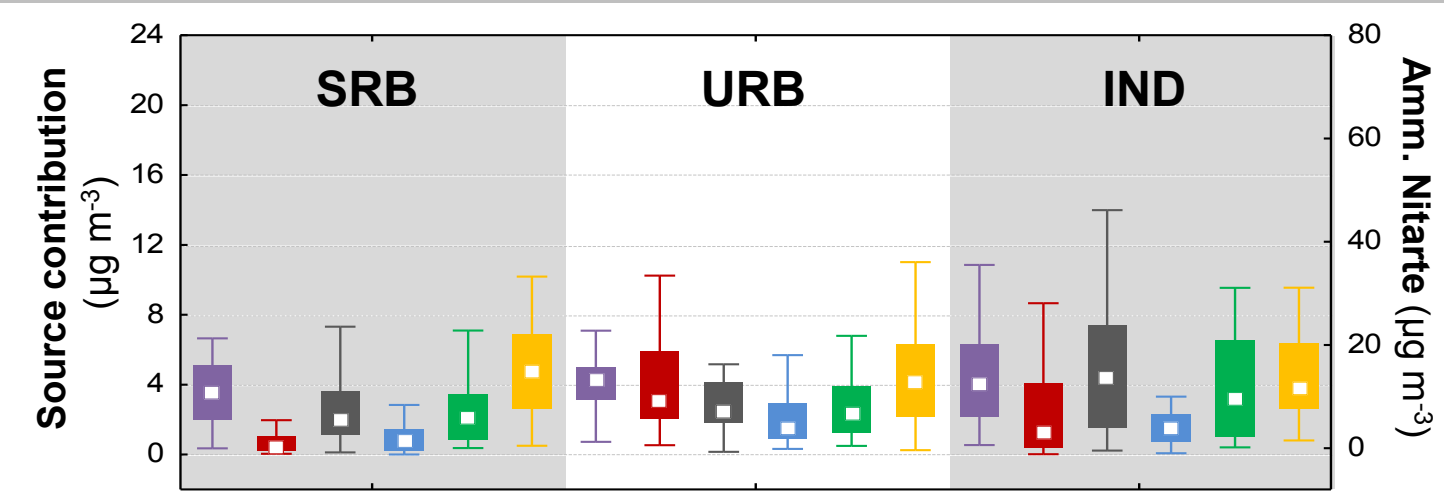

\section{Group 5}
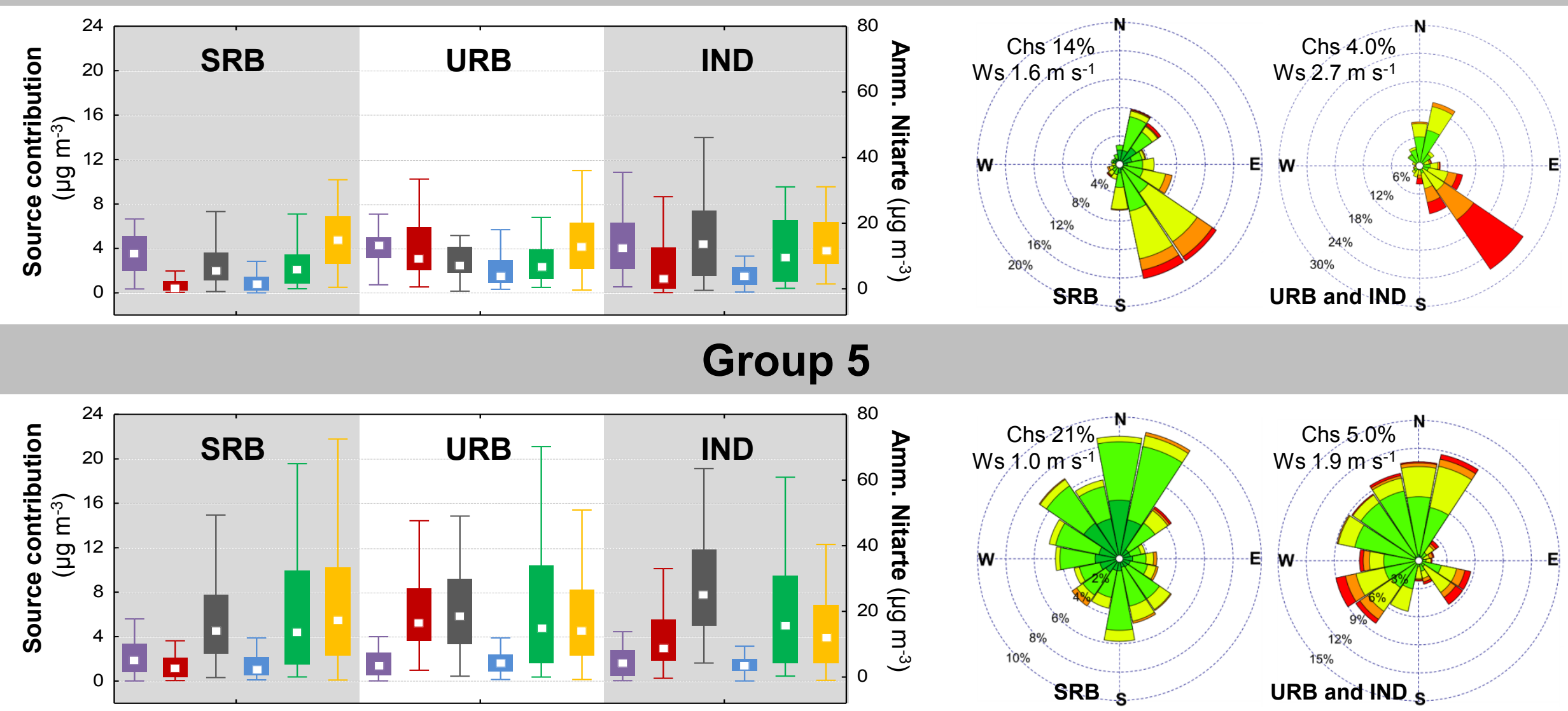


\section{HIGHLIGHTS}

- $\mathrm{PM}_{2.5}$ local and external sources have been evaluated in an European hot-spot area

- Meteorology-based methods have been applied to source apportionment results

- External contributions were evaluated applying Trajectory Statistical Methods

- Effects on PM sources of ground-wind circulation patterns were also investigated

- Local source contributions have been estimated following the Lenschow' approach 


\section{Cluster analysis on back-trajectories}

The principal purpose of back trajectories clustering is to group trajectories having similar geographic origins and histories. The subsequent coupling of clusters with chemical data associated to air pollutants is a simple but powerful way to infer insights into the potential contribution of long-range transports from different pathways. There are several ways in which clustering can be performed several measures of the similarity (e.g., Carlslaw, 2015). The Euclidean distance $(d)$ parameter is the most common technique used in a number of studies (e.g., Abdalmogith and Harrison, 2005; Owega et al., 2006; Borge et al., 2007; Markou and Kassomenos, 2010; Rozwadowska et al., 2010). It that can be defined as:

$$
d_{1,2}=\left(\sum_{i=1}^{n}\left(\left(X_{1 i}-X_{2 i}\right)^{2}+\left(Y_{1 i}-Y_{2 i}\right)^{2}\right)\right)^{1 / 2}
$$

where $\mathrm{X}_{1}, \mathrm{Y}_{1}$ and $\mathrm{X}_{2}, \mathrm{Y}_{2}$ are the latitude and longitude coordinates of back trajectories 1 and 2, respectively, and $n$ is the number of back trajectory points (96 hours in this case). In this study a non-hierarchical clustering method (K-Means) has been applied. The appropriate number of clusters has been selected by using the analysis of the total spatial variance (TSV), individuating when a large change in TSV occurs.

\section{PSCF}

The PSCF was initially developed to identify the likely locations of the regional PM sources (Lee and Hopke, 2006; Pekney et al., 2006) and calculates the probability that a source is located at latitude $i$ and longitude $j$. The basis of PSCF is that if a source is located at coordinates $i$ and $j$, an air parcel back-trajectory passing through that location indicates that material from the source can be collected and transported along the trajectory to the receptor site. PSCF solves:

$$
P S C F=\frac{m_{i j}}{n_{i j}}
$$

where $n_{i j}$ is the total number of end points that fall in the ijth cell and $m_{i j}$ is the number of end points in the same cell that are associated with samples that exceeded the threshold criterion (Carslaw, 2015). The PSCF value can be interpreted as the conditional probability that concentrations larger than a given criterion value are related to the passage of air parcels through a grid cell with this PSCF value during transport to the receptor site (Hsu et al., 2003). This method is suitable for obtaining first knowledge of possible source regions (Dvorska et al., 2008 and references therein). Generally, PSCF values of $0.00-0.50$ are considered as low, values of $0.51-1.00$ are considered as high. In this study, PSCF has been calculated using the 75th percentile of source contribution as threshold criterion. 


\section{CWT}

The main limitation of PSCF analysis is that grid cells can have the same PSCF values from samples of slightly higher or extremely higher criterion concentrations. As a consequence, larger sources cannot be distinguished from moderate ones. The concentration weighted trajectory (CWT) is a method of weighting trajectories with associated concentrations (Hsu et al., 2003). In this procedure, each grid cell gets a weighted concentration obtained by averaging sample concentrations that have associated trajectories that crossed that grid cell as follows, i.e. each concentration is used as a weighting factor for the residence times of all trajectories in each grid cell and then divided by the cumulative residence time from all trajectories (Hsu et al., 2003; Cheng et al., 2013):

$$
C_{i j}=\frac{1}{\sum_{l=1}^{M} \tau_{i j l}} \sum_{l=1}^{M} C_{l} \tau_{i j l}
$$

Where $C_{i j}$ is the average weighted concentration in the grid cell $(i, j) . \mathrm{C}_{l}$ is the measured concentration (source contributions in this study), $\tau_{i j l}$ is the number of trajectory endpoints in the grid cell $(i, j)$ associated with the $C_{l}$ sample, and $M$ is the number of samples that have trajectory endpoints in grid cell $(i, j)$. In summary, weighted concentration fields show concentration gradients across potential sources and highlight the relative significance of potential sources (Hsu et al., 2003).

\section{CPF}

The conditional probability function (Kim et al., 2003a; Kim and Hopke, 2004) analyses local source impacts from varying wind directions using the source contribution estimates from PMF coupled with the time-resolved wind directions. The CPF estimates the probability that a given source contribution from a given wind direction will exceed a predetermined threshold criterion.

$\mathrm{CPF}$ is defined as:

$$
C P F=\frac{m_{\Delta \theta}}{n_{\Delta \theta}}
$$

where $m_{\Delta \theta}$ is the number of occurrences from wind sector $\Delta \theta$ (11.25 degree) that exceeded the threshold criterion, and $n_{\Delta \theta}$ is the total number of data from the same wind sector. To minimize the effect of the atmospheric dilution, the daily fractional contributions from each source relative to the total of all sources were used rather than the absolute source contributions (Kim et al., 2003a). The same daily fractional contribution was assigned to each hour of a given day to match the hourly wind data; hence $24 \mathrm{~h}$ was set as threshold criterion for $n_{\Delta \theta}$. Calm winds $\left(<1 \mathrm{~m} \mathrm{~s}^{-1}\right)$ were excluded from this analysis due to the isotropic behaviour of wind vane under calm winds. The threshold 
criterion has been fixed to the upper $25^{\text {th }}$ percentile of the fractional contribution of each source according to most previous studies (Kim et al., 2003b; Kim and Hopke, 2004; Kim et al., 2005). The sources are likely to be located at the directions that have high conditional probability values (Kim et al., 2005).

\section{References}

Abdalmogith, S. S., Harrison, R. M., 2005. The use of trajectory cluster analysis to examine the long-range transport of secondary inorganic aerosol in the UK. Atmos. Environ. 39, 66866695.

Borge, R., Lumbreras, J., Vardoulakis, S., Kassomenos, P., Rodríguez, E., 2007. Analysis of longrange transport influences on urban PM10 using two-stage atmospheric trajectory clusters. Atmos. Environ. 41, 4434-4450.

Carslaw, D.C., 2015. The openair manual - open-source tools for analysing air pollution data. Manual for version 1.1-4, King's College London.

Cheng, I., Zhang, P., Blanchard, P., Dalziel, J., Tordon, R., 2013. Concentration-weighted trajectory approach to identifying potential sources of speciated atmospheric mercury at an urban coastal site in Nova Scotia, Canada. Atmos. Chem. Phys. 13, 6031-6048.

Dvorska, A., Lammel, G., Klanova, J., Holoubek, I., 2008. Kosetice, Czech Republic - ten years of air pollution monitoring and four years of evaluating the origin of persistent organic pollutants. Environ. Pollut. 156, 403-408.

Hsu, Y., Holsen, T.M., Hopke, P.K., 2003. Comparison of hybrid receptor models to locate PCB sources in Chicago. Atmos. Environ. 37, 545-562.

Kim, E., Hopke, P.K., Edgerton, E.S., 2003a. Source Identification of Atlanta Aerosol by Positive Matrix Factorization. J. Air Waste Manage. Assoc. 53, 731-739.

Kim, E., Larson, T. V., Hopke, P. K., Slaughter, C., Sheppard L. E., Claiborn, C., 2003b. Source identification of PM2.5 in an arid Northwest U.S. City by positive matrix factorization. Atmos. Res. 66, $291-305$.

Kim, E., Hopke, P. K., 2004. Comparison between Conditional Probability Function and Nonparametric Regression for Fine Particle Source Directions. Atmos. Environ. 38, 4667 4673.

Kim, E., Hopke, P.K., Kenski, D.M., Koerber, M., 2005. Sources of Fine Particles in a Rural Midwestern U.S. Area. Environ. Sci. Technol. 39, 4953-4960.

Lee, J.H., Hopke, P.K., 2006. Apportioning sources of PM2.5 in St. Louis, MO using speciation trends network data. Atmos. Environ. 40, 360-377.

Markou, M.T., Kassomenos, P., 2010. Cluster analysis of five years of back trajectories arriving in Athens, Greece. Atmos. Res. 98, 38-457. 
Owega, S., Khan, B.-U.-Z., Evans, G. J., Jervis, R. E., Fila, M., 2006. Identification of long-range aerosol transport patterns to Toronto via classification of back trajectories by cluster analysis and neural network techniques. Chemometr. Intell. Lab. 83, 26-33.

Pekney, N. J., Davidson, C. I., Zhou, L., Hopke, P. K., 2006. Application of PSCF and CPF to PMF-Modeled Sources of PM2.5 in Pittsburgh. Aerosol Sci. Technol. 40, 952-961.

Rozwadowska, A., Zieliński, T., Petelski, T., and Sobolewski, P., 2010. Cluster analysis of the impact of air back-trajectories on aerosol optical properties at Hornsund, Spitsbergen. Atmos. Chem. Phys. 10, 877-893. 


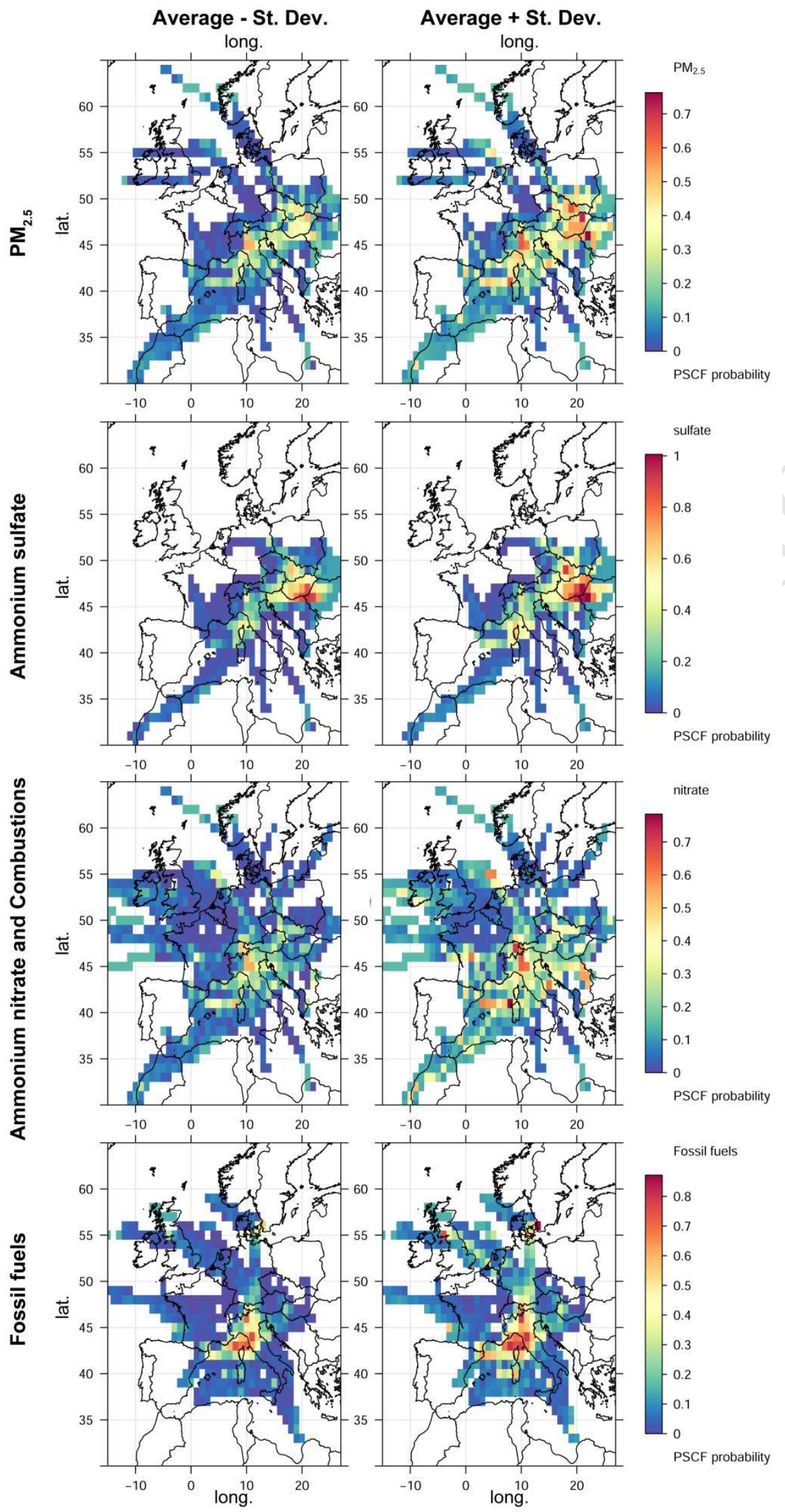

Figure SI1a. Associated uncertainties for PSCF expressed as average \pm standard deviation of $n=500$ bootstrap resamples. 


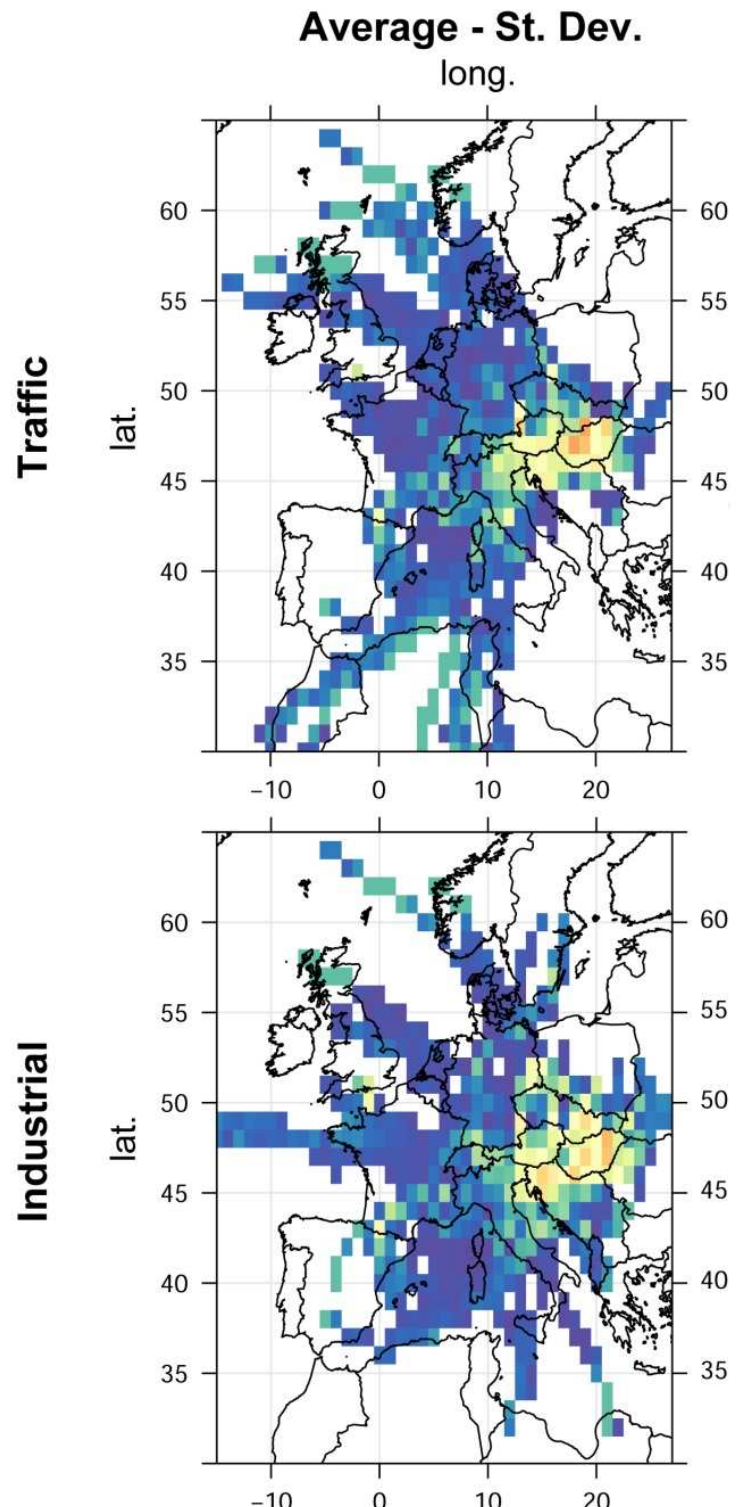

Average + St. Dev.

long.

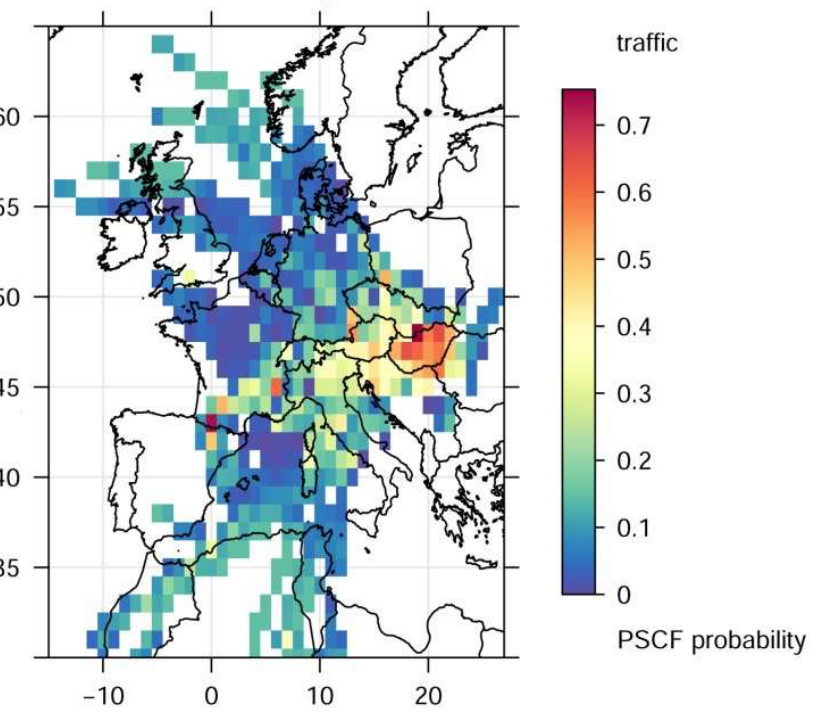

$\begin{array}{llll}-10 & 0 & 10 & 20\end{array}$
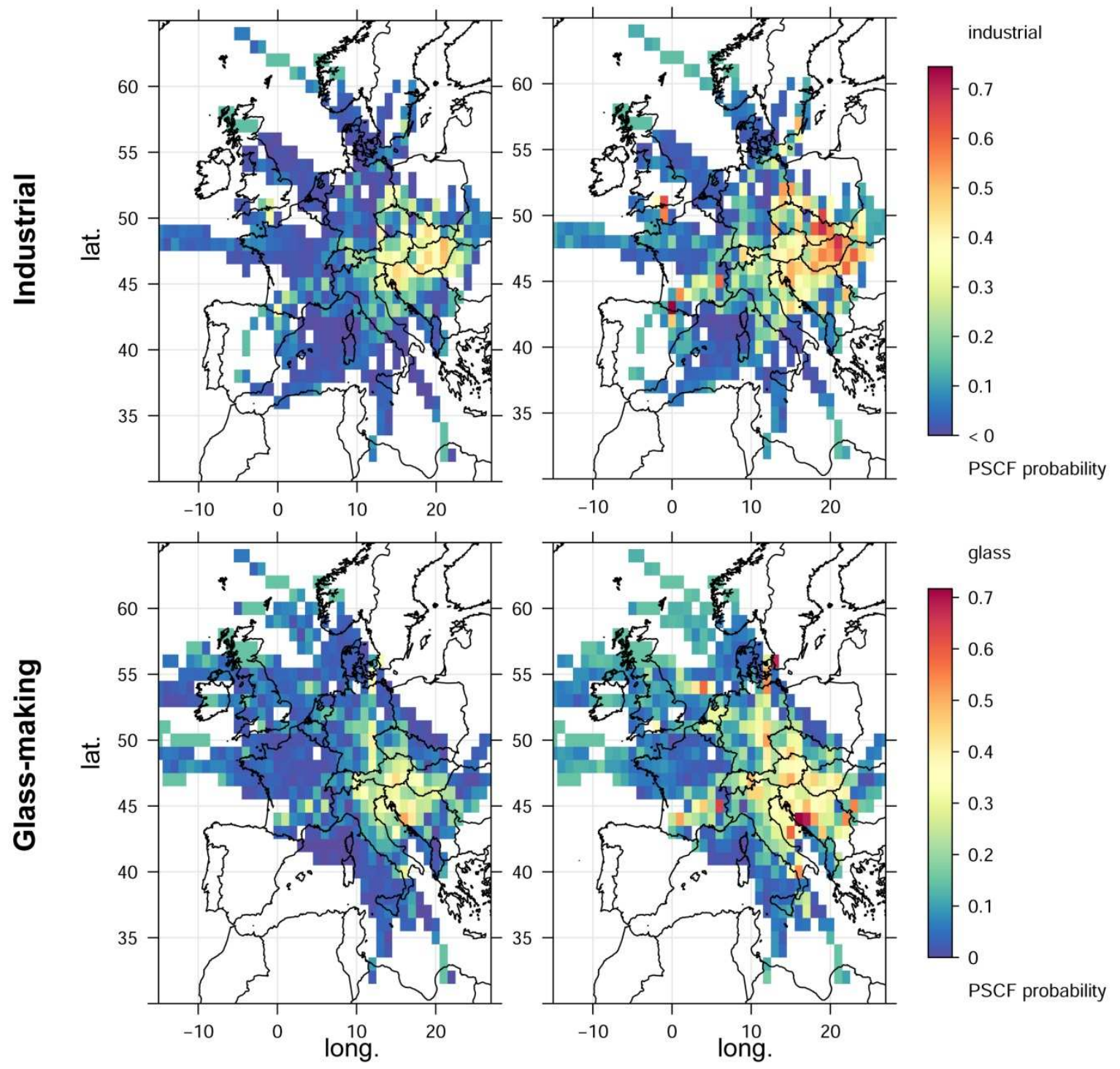

Figure SI1b. Associated uncertainties for PSCF expressed as average \pm standard deviation of $n=500$ bootstrap resamples. 